

\section{Sumário}

I. Crônicas do Direito Internacional ...............................................1

REPARAÇÃo DE VÍTIMAS À LUZ DE UM TRATAdo SOBRE EMPRESAS E DIREITOS HUMANOS ............ 3 Ana Cláudia Ruy Cardia

Consumer Social Responsibility as a Requirement for Corporate Social ResponsibiliTY

Nitish Monebhurrun

Crisis in Venezuela: The Brazilian response to the massive flow of Venezuelans in

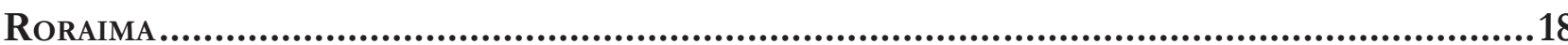

Jacqueline Salmen Raffoul

II. Dossiê EsPecial: Business and Human Rights.........................................23

Some remarks on the third sessions of the Business and Human Rights Treaty Pro-

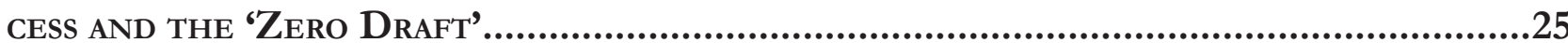

Humberto Cantú Rivera

The United Nations guiding principles on business and human Rights, the State

DUTY TO PROTECT HUMAN RIGHTS AND THE STATE-BUSINESS NEXUS.

Mihaela Maria Barnes

HARdening SOFT LAW: ARE THE EMERging Corporate SOCIAL DisClOSURE LAWS CAPABLE OF GENERATING SUBSTANTIVE COMPLIANCE WITH HUMAN RIGHTS?

Justine Nolan

Del Documento de Elementos al Draft 0: apuntes jurídicos respecto del posible CONTENIDO DEL PROYECTO DE INSTRUMENTO VINCULANTE SOBRE EMPRESAS TRANSNACIONALES

Y OTRAS EMPRESAS CON RESPECTO A LOS DERECHOS HUMANOS

Adoración Guamán 
ACCESS TO REMEDIES AND THE EMERGING ETHICAL DILEMMAS: CHANGING CONTOURS WITHIN THE BUSINESS-HUMAN RIGHTS DEBATE

Justin Jos

LA RESPONSABILIDAD PENAL DE LAS EMPRESAS POR GRAVES VIOLACIONES DE DERECHOS HUMANOS: PRÁCTICA ACTUAL Y DESAFÍOS FUTUROS 130

Daniel Iglesias Márquez

THE ENVIRONMENTAL LAW DIMENSIONS OF AN INTERNATIONAL BINDING TREATY ON BUSINESS AND HUMAN RIGHTS

Juan Gabriel Auz Vaca

Los Objetivos de Desarrollo Sostenible en Europa y su Intersección con el Marco de los Negocios y los Derechos Humanos

Paolo Davide Farah

HumAN RIGHTS AND MARKET ACCESS 203

Danielle Mendes Thame Denny

BusinesS AND HUMAN RIGHTS IN BRAZIL: EXPLORING HUMAN RIGHTS DUE DILIGENCE AND OPERATIONAL-LEVEL GRIEVANCE MECHANiSMS IN THE CASE OF KinRoss PARACATU Gold Mine...222 Mariana Aparecida Vilmondes Türke

Human Rights and eXtractive industries in Latin America: What Responsibility of CORPORATIONS AND THEIR STATES OF ORIGIN FOR HUMAN RIGHTS VIOLATIONS IN THE INTER-American Human Rights System?.

Alberto do Amaral Junior e Viviana Palacio Revello

MultinaCiOnAIS FAST FASHION E DIREITOS HUMANOS: EM BUSCA DE NOVOS PADRÕES DE RESPONSABILIZAÇÃO 255

Laura Germano Matos e João Luis Nogueira Matias

III. Artigos sobre outros temas

EFFICIENCY AND EFFICACY OF PUBLIC FOOD PROCUREMENT FROM FAMILY FARMERS FOR SCHOOL FEEDING IN BRAZIL. 271

Rozane Márcia Triches 
A relaÇão ENTRE O GRAU de INTEGRaÇÃo ECONÔMiCA E O SISTEMA DE SOLUÇÃo DE CONTROvÉRSIAS: UM ESTUdo COMPARATIVO ENTRE A UNIÃo EURopeia E O MERCOSUl.....................286

Luciane Klein Vieira e Elisa Arruda

THE RIGHTS TO MEMORY AND TRUTH IN THE INTER-AMERICAN PARADIGMS OF TRANSITIONAL JUSTICE: THE CASES OF BRAZIL AND CHILE 308

Bruno Galindo

Juliana Passos de Castro

A margem nacional de apreciação na Corte Interamericana de Direitos Humanos.325 Gilberto Schäfer, José Eduardo Aidikaitis Previdellie e Jesus Tupã Silveira Gomes

Novos Direitos FUNDAMENTAIS NO ÂMBITo DA UNASUL: ANÁLISE DAS AGENDAS DE Brasil E VENEZUELA À LUZ DO DIREITO À PAZ.

Pedro Pulzatto Peruzzo e Arthur Ciciliati Spada

A atuação do Grupo Mercado Comum frente À Criminalidade organizada transnacio-

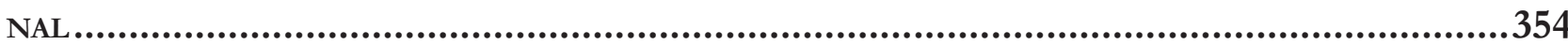

Sabrina Cunha Kesikowski, Luis Alexandre Carta Winter e Eduardo Biacchi Gomes

COUNTER-TERRORISM LEGISLATION AND TERRORIST ATTACKS: DOES HUMAN RIGHTS HAVE SPACE?

Heloisa Tenello Bretas e Daniel Damásio Borges

Territórios da ViolênCia de GÊNERo: NORMATIVA INTERNACIONAL E os Casos "CAMpo AlGodoeiro” (MÉXICO) - “Morro do Garrote” (BrasiL)

Eugênia Nogueira do Rêgo Monteiro Villa e Bruno Amaral Machado

O USO DE MECANISMOS INFORMAIS DE GOVERNANÇA GLOBAL E SUA APLICABILIDADE NAS LICITAÇÕES PÚBLICAS BRASILEIRAS.

Fabiano de Figueiredo Araujo e Paulo Afonso Cavichioli Carmona

Autonomia INSTITUCIONAL DA IGREJA CATÓliCA E A INGERÊNCIA INDEVIDA DO ESTADO BRASILEIRo POR EVENTUAIS Ilícitos CANÔNicos: ANÁlise do CASO de Formosa-GO, À luz do TraTADo Brasil-Santa SÉ de 2010 
A MORE TARGETED APPROACH TO FOREIGN DIRECT INVESTMENT: THE ESTABLISHMENT OF SCREENING SYSTEMS ON NATIONAL SECURITY GROUNDS

Carlos Esplugues Mota

IV. RESENHAS 467

Direito Internacional em Perspectiva Transcivilizacional de Yasuaki Onuma........469 Arthur Roberto Capella Giannattasio

Resenha do livro Space, Global Life: The Everyday Operation of International LaW and Development, de Luis Eslava .473

Matheus Gobbato Leichtweis

QUEM TEM MEDO DO PÓS-COLONIAL NO DIREITO INTERNACIONAL? UMA RESENHA DE "DECOLONISING INTERNATIONAL LAW: DEVELOPMENT, ECONOMIC GROWTH AND THE POLITICS OF UNIVERSAlity" de Sundhya Pahuja

Gabriel Antonio Silveira Mantelli

Direitos humanos COMO UM NOVO PROJETO PARA O Direito INTERNACIONAL? Notas sobre The Last Utopia, de Samuel Moyn .490 João Roriz 


\title{
A more targeted approach to foreign direct investment: the establishment of screening systems on national security grounds*
}

\author{
Uma abordagem mais específica ao \\ investimento estrangeiro directo: 0 \\ estabelecimento de sistemas de triagem \\ fundamentados na segurança nacional
}

Carlos Esplugues Mota**

\begin{abstract}
The process of liberalization of international trade and of Foreign Direct Investment (FDI) has constituted a broadly accepted trend during the last few decades and FDI inflows have expanded constantly since the end of the 1980's. However, signs of a certain crisis of the positive and one-way attitude towards international trade and FDI exist nowadays. The increase in the flux of FDI coming from developing and emerging countries to developed economies, the sudden relevance of foreign sovereign investors, the changing environment for national security or the quest to protect technologies and sectors of the economy considered vital for the host country, its sovereignty and competitiveness are creating a new reality that impacts on both, the global fluxes of FDI and its regulation. Tension exists between the commitment towards freedom of FDI and the right of the state to ensure that certain legitimate public interests and goals can be fully implemented. This may lead to the protection of certain strategic sectors of the economy of the country or flagship firms from foreign investment on national security or related grounds. The current revision of the great paradigms on which FDI, and its legal framework, stand is ascertainable in the growing recourse by states to the development of some measures devoted to prevent the entrance of FDI in the country under certain circumstances.
\end{abstract}

* Recebido em 15/06/2018

Aprovado em 16/07/2018

** Carlos Esplugues, LLM(Harvard), MSc(Edinburg) es Catedrático de Derecho internacional privado y Derecho del comercio internacional de la Universidad de Valencia (España). Con cerca de 500 publicaciones de amplio impacto internacional entre libros, capítulos de libro y artículos publicados en español, inglés, japónes $\mathrm{y}$ ruso en editoriales y revistas nacionales e internacionales de primera línea, es también director de dos manuales de referencia en España y Latinoamérica sobre Derecho internacional privado y Derecho del Comercio internacional. Carlos Esplugues actúa también regularmente como árbitro y mediador internacional. Email: Carlos.esplugues@uv.es
Keywords: Foreign Direct Investment (FDI). Foreign investment and national security. Freedom of Investment. Control of FDI. Barriers to foreign investment. Screening systems of control. Restrictions to foreign investment.

\section{Resumo}

O processo de liberalização do comercio internacional e do investimento direto estrangeiro (FDI) tem constituído um assunto amplamente aceito durante as últimas décadas e o fluxo do FDI tem sido expandido constantemente desde finais dos anos 1980's. Porém, existem atualmente sinais de certa crise da atitude positiva sobre o comércio internacional e FDI. O aumento do fluxo de IED proveniente de países emergentes e em 
desenvolvimento para economias desenvolvidas, a súbita relevância de investidores soberanos estrangeiros, o ambiente em transformação para a segurança nacional ou a procura da proteção de tecnologias e setores da economia considerados vitais para o país anfitrião, sua soberania e competitividade estão criando uma realidade que afeta tanto os fluxos globais de IDE quanto sua regulamentação. Existe uma tensão entre o compromisso com a liberdade do IDE e o direito do Estado de assegurar que certos interesses públicos legítimos possam ser plenamente implementados. Isso pode levar à proteção de certos setores estratégicos da economia do país ou de firmas emblemáticas do investimento estrangeiro em segurança nacional ou áreas relacionadas. A atual revisão dos grandes paradigmas sobre os quais o FDI e seu arcabouço legal, se encontra é verificável no crescente recurso dos Estados ao desenvolvimento de algumas medidas destinadas a impedir a entrada do FDI no país sob certas circunstâncias.

Palavras-chave: Investimento estrangeiro direto (FDI). Investimento estrangeiro e segurança nacional. Controle do FDI. Barreiras ao investimento estrangeiro. Sistema de controle. Restrições ao investimento estrangeiro.

\section{INTRODUCTION}

The process of liberalization of international trade and of Foreign Direct Investment (FDI) has constituted a broadly accepted trend during the last few decades. ${ }^{1}$ In contrast with other periods of time in history, since the beginning of 1990s FDI is, as a matter of principle, welcomed in most countries. ${ }^{2}$ National entry conditions for

1 GOLUB, Stephen S. Measures of Restrictions on Inward Foreign Direct Investment for OECD Countries. Paris: OECD, 2003. p. 1. (Economic Department Working Papers, No. 357, OECD Publishing). p. 1.

2 The growth of FDI has traditionally been considered an element for stability and peace that is much stronger than trade or portfolio investment. As an example of the implementation of the theory of self-enforcing cooperation, the greater the exposure of one country to FDI coming from another country is, the conflict with that country is less possible. ROSECRANCE, Richard; THOMPSON, Peter. "Trade, Foreign Investment, and Security". Annual Review of Political Science, v. 6, p. 390-391, 2003. At the same time, the more trade a country has with another country, fewer possibilities to enter into conflicts with that country exist because the mutual dependence makes conflict more costly, see DIXIT, Avinash. "International Trade, Foreign Direct Investment, and Security". The Annual Review of Economics, v. 3, p. 191, 2011.
MNEs have been liberalized, the operation of foreign affiliates once established in the host country has been facilitated and measures of all kinds to attract FDI have been implemented, for instance, the establishment of investment promotion agencies. ${ }^{3}$

FDI inflows have expanded constantly since the end of the 1980's. World FDI flows averaged around US $\$ 50$ billion at the beginning of the 1980s. They jumped to US $\$ 200$ billion by 1990 and 25 years later, reached US $\$ 1.23$ trillion in $2014,{ }^{4}$ two thirds of its 2007 pick. $^{5}$ In 2016, Global FDI flows decreased flows decreased by 7 per cent to US\$ 1625 billion compared to $2015 .^{6}$

However, signs of a certain crisis of the positive and one-way attitude towards international trade and FDI exist today. Nowadays emerging economies are in many cases major players in the world economy and play a leading role in the field of FDI. ${ }^{7}$ The increase in the flux

3 SAUVANT, Karl P. FDI Protectionism Is on the Rise, Policy Research Working Paper 5052, The World Bank Poverty Reduction and Economic Management Network, International Trade Department World Bank, Washington, September 2009. p. 3. Around 8 000 different FDI promotion agencies are said to exist worldwide. ECONOMOU, Persephone; SAUVANT, Karl P. "Recent Trends and Issues in Foreign Direct Investment 2010". Yearbook on International Investment Law \& Policy, v. 3, p. 1, 2010-2011. And the number of members of the World Association of Investment Promotion Agencies (WAIPA) - the Association of Investment Promotion Agencies which was established in 1995- increases constantly and it has today 170 members from 130 countries (Note World Association of Investment Promotion Agencies, <http://waipa.org/> accessed 11 November 2017). At the same time and with the final goal of fostering the competitiveness of national firms, many countries also support outwards FDI by national investors by, for example, providing them with information about investment opportunities, helping them to obtain feasibility studies, offering insurance for outwards FDI projects or concluding bilateral treaties for the protection and promotion of FDI.

4 For an analysis of the development of flows, note OECD. FDI in Figures. April 2017. 1-2. Available in: <http://www.oecd.org/daf/ inv/investment-policy/FDI-in-Figures-April-2017.pdf>. Access on: 13 Jul. 2018.

5 UNITED NATIONS CONFERENCE ON TRADE AND DEVELOPEMENT. World Investment Report 2015. Reforming International Investment Governance. New York and Geneva: United Nations, 2015. p. 25; OECD. Roundtable on Freedom of Investment 20. 19 March 2014 Summary of Roundtable discussions by the OECD Secretariat. Paris: OECD, 2014. p. 3.

6 ORGNISATION FOR ECONOMIC CO-OPERATION AND DEVELOPMENT. FDI in Figures. April 2017. 1-2. Available in: <http://www.oecd.org/daf/inv/investment-policy/FDI-in-Figures-April-2017.pdf>. Access on: 27 Nov. 2017.

7 But some countries show a certain inability to accept this reality; they still have difficulties to admit the "new kids on the block", see SAUVANT, Karl P. "Is the United States Ready for FDI from China? Overview”. In: SAUVANT, Karl P. (Ed.). Investing in the United States Is the US Ready for FDI from China, Studies in International Invest- 
of FDI coming from developing and emerging countries to developed economies, the sudden relevance of foreign sovereign investors or the increasingly negative attitude of the population towards globalization and the socioeconomic effects of Mergers and Acquisitions (M\&As) of domestic firms by foreigners. As well as the changing environment for national security or the quest to protect technologies and sectors of the economy considered vital for the host country, its sovereignty and competitiveness are creating a new reality that will necessarily affect both, the legal framework and the global fluxes of FDI.

All these facts, among others, have a direct impact in the assessment of free trade and free flows of FDI in many states, especially developed ones, and leads to the implementation of mechanisms of control of FDI on national security or related grounds in particular countries of the world. Liberalization of FDI constitutes a strong trend that will probably continue in the future. However some signs of "backlash against FDI" exist that make the regulatory framework less welcoming in certain countries as regards foreign investments or, at least, as regards foreign investments coming from certain countries, sovereign-driven FDI or FDI directed to certain areas of the economy. A trend that, in any case, may favour a more targeted approach towards FDI flows in the near future.

\section{GLobalization, FREE TRADE AND FREe fLOWS OF FDI IN THE SPOTLIGHT}

The phenomenon of globalization is directly related to the liberalization of international trade and international investment. ${ }^{9}$ They are simultaneously the cause and manifestation of this fact. The three sets of FDI

ment. Edward Elgar: Cheltenham/Northampton, 2009. p. 2.

8 SACHS, Lisa E.; SAUVANT, Karl P., "BITs, DTTs, and FDI Flows: An Overview", In: SAUVANT, Karl P.; SACHS, Lisa E. The Effect of Treaties on Foreign Direct Investment. Bilateral Investment Treaties, Double Taxation Treaties, and Investment Flows. Oxford: OUP, 2009. p. xxvii \& lix, xxx.

9 LEAL-ARCAS, Rafael. "Towards the Multilateralization of International Investment Law". The Journal of World Investment \& Trade, v. 10, p. 865-866, 2009; SALACUSE, Jeswald W. The Three Laws of International Investment. National, Contractual and International Frameworks for Foreign Capital. Oxford: OUP, 2013. p. 351-2; FONTAGNÉ, Lionel. Foreign Direct Investment and International Trade: Complements or Subtitutes? Paris: OECD Science, Technology and Industry Working Papers, 1993/03, OECD Publishing, 1993. p. 5. determinants -economic conditions, the regulatory framework and investment promotion $-^{10}$ have lined up favourably during the last few decades. And FDI has grown steadily due to the combination of certain factors of a varied and differing nature ranging from the connectivity revolution and the technological developments that facilitate the managing of international business systems in an integrated manner, the changing pattern of Competition Law, the procedure of deregulation undertaken in many economies, the process of integration developed in several parts of the world, the increasing liberalization of international trade or of FDI policies by national states. ${ }^{11}$

However, globalization has an increasingly negative understanding for many people in some countries as does free trade in many sectors of the population, and this has a direct and growing influence on the approach to FDI by some national governments. The idea of globalization and international trade, and consequently that of free flows of FDI, being under siege is spreading rapidly all over the world. The traditionally rather innocuous area of investment law is nowadays under pressure, not only in relation to inwards FDI (IFDI) but also as regards to outwards FDI (OFDI). ${ }^{12}$ More and more some developed countries are starting to feel disquiet with respect to the FDI regime that they have helped construct for decades. ${ }^{13}$ And the contradictions and tensions that have traditionally accompanied FDI are now superseded by the rising mistrust towards globali-

10 SAUVANT, Karl P. “The FDI recession has begun”. In: SAUVANT, Karl P. et al. FDI Perspectives Issues in International Investment. New York: Vale Columbia Center on Sustainable International Investment, Columbia University, 2011. p. 7.

11 BITZENIS, Aristidis. Globalization and Foreign Direct Investment. In: BITZENIS, Aristidis, VLACHOS, Vasileios A.; PAPADIMITRIOU, Pyrros. (Ed.). Mergers and Acquisitions as the Pillar of Foreign Direct Investment. New York: Palgrave McMillan, 2012. p. 10; FONTAGNÉ, Lionel. Foreign Direct Investment and International Trade: Complements or Subtitutes? Paris: OECD Science, Technology and Industry Working Papers, 1993/03, OECD Publishing, 1993. p. 9; SACHS, Jeffrey D. "Foreign Investment and the Changing Global Economic Reality”. In: ALVAREZ, José E. et al. (Ed.). The Evolving International Investment Regime Expectations. Oxford: Realities, Options, OUP, 2011. p. xlvii-xlix; LEE, Yong-Shik. Foreign Direct Investment and Regional Trade Liberalization: A Viable Answer for Economic Development? Journal of World Trade, v. 39, n. 4, p. 701, 2005. p. $701,702$.

12 ALVAREZ, José E. "Contemporary Foreign Investment Law: An "Empire of Law" or the "Law of Empire"?" Alabama Law Review, v. 609, p. 943-970, 2009.

13 ALVAREZ, José E. "Contemporary Foreign Investment Law: An "Empire of Law" or the "Law of Empire"?" Alabama Law Review, v. 609, p. 972-975, 2009. 
zation and free trade that is arising in certain countries. ${ }^{14}$

This combination of factors favours a rapid change in the approach to FDI in many states, which takes place in an atmosphere of growing prevention as regards some of the consequences arising out of globalization is rapidly favouring protectionism and creating a new element of pressure on the freedom of FDI. Foreign ownership of national firms is negatively approached by citizens, both in developed and emerging countries. ${ }^{15}$ But not only IFDI is under scrutiny, also OFDI may be affected by the current reality in many places.

FDI is more intrusive than trade because it involves the entire range of issues related to the process of production. ${ }^{16}$ In fact, the increase in the flux of FDI has been one of the factors that have led to a big transformation in the industrial structure of many modern economies. ${ }^{17}$ Developed economies originally produced most of their products at home, but because of the costs, production and plants have been increasingly diverted abroad..$^{18}$ In the 1980 s Japanese companies produced around 5 per cent of their products overseas and it is projected to rise to 24.2 per cent in $2020 .{ }^{19}$ In the case of the US, in 2013 around 53 per cent of manufacturing companies took advantage of offshore outsourcing and more than two million jobs were outsourced. ${ }^{20}$

14 SAUVANT, Karl P. "Driving and Countervailing Forces: A Rebalancing of National FDI Policies". Yearbook on International Investment Law \& Policy, p. 215-234, 2008.

15 SAUVANT, Karl P. "Driving and Countervailing Forces: A Rebalancing of National FDI Policies". Yearbook on International Investment Law \& Policy, p. 244-262, 2008.

16 FDI can compensate trade immobility insofar as FDI former exporters can produce and sell abroad even when high tariffs to trade are introduced. Note, ROSECRANCE, Richard; THOMPSON, Peter. "Trade, Foreign Investment, and Security". Annual Review of Political Science, v. 6, p. 394, 2003.

17 SAUVANT, Karl P. "The Rise of International Investment, Investment Agreements and Investment Disputes". In: SAUVANT, Karl P.; WITH CHISWICK-PATTERSON, Michael. (Ed.). Appeals Mechanism in International Investment Disputes. New York: OUP, 2008. p. 11.

18 Additionally, manufacturing has shifted to services in many modern developed economies ROSECRANCE, Richard; THOMPSON, Peter. "Trade, Foreign Investment, and Security". Annual Review of Political Science, v. 6, p. 384-385, 2003.

19 CABINET OFFICE, ECONOMIC AND SOCIAL RESEARCH INSTITUTE. FY2015 Annual Survey of Corporate Behavior. Press Release, Tokio, 26 June 2016. Available in: <http://www.esri. cao.go.jp/en/stat/ank/h27ank/h27ank_press.pdf>. Access on: 13 Jul. 2018.

20 STATISTIC BRAIN. Job Overseas Outsourcing Statistics. Available in: <http://www.statisticbrain.com/outsourcing-statisticsby-country/>. Access on: 13 Jul. 2018. In the last US presidential
It is not only that certain areas of the economy should be preserved from foreign investment for the national interest or on national security grounds, it is also that national corporations should be deterred in certain cases and sectors of the market from investing abroad in so far as this is deemed to potentially cause a haemorrhage of jobs, knowledge and standing for the country.

\section{A MORE TARGETED APPROACH TOWARDS FDI FLOWS}

FDI is increasingly subject to changes. FDI both inwards and outwards is not as welcome as before. ${ }^{21}$ Liberalization of trade and investment is approached by some countries and social groups as dangerous in so far as, and among other reasons, the country may rely too much on foreign importations or some key sectors of the economy or industries may be controlled by foreigners or foreign countries. Tension exists between the commitment towards freedom of FDI and the right of the state to ensure that certain legitimate public interests and goals can be fully implemented. This may lead to the protection of certain strategic sectors of the economy of the country or flagship firms from foreign investment on national security, national essential security interests or related grounds.

This leads to the existence of a strong trend to provide governments with broader powers to decide what FDI they want, and which one they don't. These objectives are ensured and reached through different mechanisms and policies fixed by the state itself. And it may lead governments, now also from developed countries, to pay more attention, among other things, to some competing objectives like the safeguard of special national interests or of essential security interests, the promotion of national champions or the protection of certain national industries and critical infrastructures. ${ }^{22}$.

election of 2016, the issue of delocalization and outwards FDI and their influence on the loss of jobs was one of the issues of major relevance.

21 WAYMOUTH, Crispin. 'Is 'Protectionism' a Useful Concept for Company Law and Foreign Investment Policy? An EU Perspective". In: BERNITZ, Ulf; RINGE, Wolf-Georg. (Ed.). Company Law and Economic Protectionism New Challenges to European Integration. Oxford: OUP, 2010. p. 35-6.

22 These policies are based on a comprehensive approach to security risk management and respond in many cases to the broad understanding of the ideas of national security or essential secu- 
No state has ever granted unrestricted entry to foreign investors and some limits to them have always existed. But nowadays some states and political actors are starting to think of whether they have relinquished "too much "policy space" in signing International Investment Agreements (IIAs) that through their interpretation by international arbitration panels may cast a "regulatory chill" over domestic measures that are considered to be needed to achieve legitimate, non-investment policy objectives, not only in the economic field but also as regards other ambits like health and safety policy objectives, or national security as well as human rights or environmental protection. ${ }^{23}$ They also wonder whether it is acceptable that key elements of the economy or prominent industries become controlled by foreign investors, some of them sovereign driven investors belonging to countries that do not always fully share their social, economic or democratic ideas.

The rapid industrialization of some emerging countries has raised additional concerns about the access to energy and to scarce raw materials. The protection of technologies considered vital to national sovereignty and competitiveness has also become a relevant issue to be taken into account. The control of these areas has now become a political issue with a strong connection to the area of FDI and to the national security of the host state. ${ }^{24}$ Also terrorism, the changing global geostra-

rity interests. Vid., OECD. Building Trust and Confidence in International Investment. Report by countries participating in the "Freedom of Investment" Process March 2009. Paris: OECD, 2009. p. 10. This means new rules on FDI or more rigorous enforcement of existing ones; a greater degree of conditionality attached to regulatory approval mechanisms in the host state; or reference to a more expansive notion of strategic industries, the national interest and national security. THOMSEN, Stephen; MISTURA, Fernando. Is investment protectionism on the rise? Evidence from the OECD FDI Regulatory Restrictiveness Index OECD Global Forum on International Investment. Paris: OECD, 2017. p. 1. Sometimes, the mere disapproving pronouncements by the government or fears of a popular backlash are enough to stop a potential cross-border investment in its tracks. Vid. also, SAUVANT, Karl P.; ORTINO, Federico. Improving the International Investment Law and Policy Regime: Options for the Future. Helsinki: Ministry for Foreign Affairs of Finland, 2013. p. 38.

23 SPEARS, Suzanne A. "The Quest for Policy Space in a New Generation of International Investment Agreements". Journal of International Economic Law, v. 13, n. 4, p. 1037-1040, 2010. Also consider, OECD. Interim report approved by the OECD Investment Committee at the fourth OECD Roundtable on Freedom of Investment. National Security and "Strategic" Industries on 30 March 2007 (reproduced in OECD, International Investment Perspectives: Freedom of Investment in a Changing World. Paris: OECD, 2007. p. 55.

24 ORGNISATION FOR ECONOMIC CO-OPERATION AND DEVELOPMENT. Interim report approved by the OECD Invest- tegic environment and the current atmosphere of securitization have generated additional concerns as regards FDI and have also favoured a change in the way FDI regulation is approached in certain countries. It is not only a question of preventing foreign firms from controlling strategic industries or firms, or playing a key role in the national economy, of protecting national cultural identity or avoiding national security concerns. ${ }^{25}$ It is said to be more than that: it is an issue of fear of transference of $R \& D$ departments, a sell-out of national resources, unfair subsidising, a lowering of environmental standar$\mathrm{ds}$, industrial espionage, insufficient protection of intellectual property or loss of jobs in developed countries. ${ }^{26}$

Fears increase further when the investment is undertaken by MNEs belonging to emergent countries, some of them with a high participation of foreign governments in their control, governance and determination of their final aims. ${ }^{27}$ There are growing concern by states and public opinion about the compatibility of FDI, or at least of FDI coming from certain countries and targeting certain areas of the economy, with the protection and safeguarding of some values, policies and objectives of the host state in certain areas. ${ }^{28}$

\subsection{Potential national security threats generated by FDI}

In addition to certain purely social and economic problems related to the potential change of domicile of the acquired enterprise, the loss of jobs that it can imply or the change in its management, some particular fears specifically related to national security issues

ment Committee at the fourth OECD Roundtable on Freedom of Investment. National Security and "Strategic" Industries on 30 March 2007 (reproduced in OECD, International Investment Perspectives: Freedom of Investment in a Changing World. Paris: OECD, 2007. p. 54. 25 SAUVANT, Karl P. "Driving and Countervailing Forces: A Rebalancing of National FDI Policies". Yearbook on International Investment Law \& Policy, p. 233, 2008.

26 HEINEMANN, Andreas. 'Government Control of CrossBorder M\&A: Legitimate Regulation or Protectionism? Control of Cross-Border M\&A'. Journal of International Economic Law, v. 15, n. 4, p. $843,863,2012$.

27 Note, SAUVANT, Karl P.; GOVITRIKAR, Vishwas P.; DAVIES, Ken. MNEs from Emerging Markets: New Players in the World FDI Market. New York: Vale Columbia Center, 2011. p. 1 ff. 28 OECD. Novel Features in OECD Countries' Recent Investment Agreements: An Overview. Paris: OECD, 2005. p. 4 at No. 11; VADI, Sara. "Fragmentation or Cohesion? Investment versus Cultural Protection Rules". Journal of World Investment and Values, v. 10, p. 573, 2009. 
exist in relation to FDI. Authors speak of at least three threats of diverse kinds potentially generated by FDI: the dominance of supply that penalizes the host country, the transfer of technology that harms host country interests, and the possibility of engaging in sabotage or espionage. $^{29}$

1) The first potential damage to national security arising out of a foreign M\&As refers to the possibility that the country where the acquired firm is located, becomes dependent on a foreign controlled supplier of goods or services which are crucial to the normal functioning of the host country. And this dependence can finally imply a delay, denial or the placement of conditions on the provisions of such goods or services by the foreign acquired firm. ${ }^{30}$ Nevertheless, for this threat of dependence to be credible, the industry should be tightly concentrated with a limited number of close substitutes and high switching costs. ${ }^{31}$ And in the evaluation of the competition among alternative suppliers not the local market but the global market must be considered. ${ }^{32}$

2) The second category of threats refers to those M\&As that can imply transfer of certain technology or expertise to a foreign controlled entity that could be deployed by this entity, or its government, in a manner harmful to that country's national interests. ${ }^{33}$ The asses-

29 MORAN, Theodore H., 'Foreign Acquisitions and National Security: What are Genuine Threats? What Are Implausible Worries?'. In: DRABEK, Zdenek; MAVROIDIS, Petros C. (Ed.), Regulation of Foreign Investment Challenges to International Harmonization. Singapore World Scientific, World Studies in International Economics. New York: Columbia University, 2013. v. 21. p. 372-373. Also, DOBSON, Wendy. "China's State-Owned Enterprises and Canada's Foreign Direct Investment Policy”. Canadian Public Policy, v. 43, 2017. p. S28, S41; HANEMANN, Thilo; ROSEN, Daniel H. China Invests in Europe Patterns, Impacts and Policy Implications. New York: Rhodium Group, 2012. p. 60-1.

30 MORAN, Theodore H. Chinese Foreign Direct Investment in Canada: Threat or Opportunity?. Ottawa: Canadian Council of Chief Executives/Conseil Canadien des Chiefs d'Enterprise, 2012. p. 5-6.

31 MORAN, Theodore H., 'Foreign Acquisitions and National Security: What are Genuine Threats? What Are Implausible Worries?'. In: DRABEK, Zdenek; MAVROIDIS, Petros C. (Ed.), Regulation of Foreign Investment Challenges to International Harmonization. Singapore World Scientific, World Studies in International Economics. New York: Columbia University, 2013. v. 21. p. 373.

32 MORAN, Theodore H., 'Foreign Acquisitions and National Security: What are Genuine Threats? What Are Implausible Worries?'. In: DRABEK, Zdenek; MAVROIDIS, Petros C. (Ed.), Regulation of Foreign Investment Challenges to International Harmonization. Singapore World Scientific, World Studies in International Economics. New York: Columbia University, 2013. v. 21. p. 385.

33 MORAN, Theodore H. Chinese Foreign Direct Investment in Canada: Threat or Opportunity?. Ottawa: Canadian Council of Chief sment of this threat also depends on how broadly available the additional production or managerial expertise is involved, as well as the impact of the acquisition on those who seek its output. ${ }^{34}$

3) Finally, a third category of threats are those arising out of M\&As that would allow the insertion of a certain capability for infiltration, surveillance or sabotage into the provision of certain services or goods which are deemed crucial to the normal functioning of the economy of the host country: telecommunications is one of them. ${ }^{35}$

In any case, taking these three different threats into account and leaving aside the potential political and media impact of some of the M\&As undergone in recent times, it is necessary to differentiate when approaching particular FDI proposals between genuine threats and generic which in some cases may be just excuses for the host state to adopt hidden protectionist measures.

\subsection{Factors of potential danger to be taken into account by host states}

A double-edged attitude towards FDI is growing nowadays in many parts of the world. As a matter of principle most states encourage FDI, but at the same time many of them are increasingly beginning to adopt a more selective approach in relation to it. That finally means that FDI is welcomed as a general rule, but some FDI or some kinds of FDI are not that welcome in certain cases or as regards particular targets. National security, national essential security interests or similar terms are some of the grounds used to protect the host state from undesired FDI.

FDI legislation reflects the balance between the benefits that host and home countries expect from foreign

Executives/Conseil Canadien des Chiefs d'Enterprise, 2012. p. 6.

34 MORAN, Theodore H., 'Foreign Acquisitions and National Security: What are Genuine Threats? What Are Implausible Worries?'. In: DRABEK, Zdenek; MAVROIDIS, Petros C. (Ed.), Regulation of Foreign Investment Challenges to International Harmonization. Singapore World Scientific, World Studies in International Economics. New York: Columbia University, 2013. v. 21. p. 378.

35 MORAN, Theodore H. Chinese Foreign Direct Investment in Canada: Threat or Opportunity?. Ottawa: Canadian Council of Chief Executives/Conseil Canadien des Chiefs d'Enterprise, 2012. p. 6. Note to this respect, INTELLIGENCE AND SECURITY COMMITTEE. Foreign involvement in the Critical National Infrastructure The implications for national security (Chairman: The Rt. Hon. Sir Malcolm Rifkind, MP) Presented to Parliament by the Prime Minister on behalf of Her Majesty, Cm 862, June 2013. 11 ff. 
capital and the potential risks that FDI has for them. ${ }^{36}$ And it is increasingly under pressure, especially in many western countries, which are currently re-evaluating the cost-benefit trade-off of certain types of FDI. Consequently, in certain places not all FDI is considered welcome but only some types of FDI and different instruments and devices are used to control it. The acceptance of FDI is not full and becomes increasingly qualified and made dependent on factors such as the sector or specific industry targeted by the investment, its nature -either greenfield or through M\&A of an already existing undertaking, its condition -purely private or sovereign driven- or its origin.

Reference to these concepts opens the question of determining which foreign investment can be dangerous for the host state, in other words, to specify against "what" or against "whom" is protection sought. And this is done by every state on its own. Any of these four factors, alone or a combination of some of them, activate in most cases the national system of evaluation of FDI on national security or related grounds. For instance, the origin of the investment and the quality of the investor are relevant in order to assess its potential conflict with national security. But also the political and investment climate of the host country is very relevant in the process of evaluating the potential risk of the operation in a specific moment, in a certain country and as regards a particular area of the economy. FDI may generate different concerns when it refers to nuclear power energy or to solar energy, or when the investment is proposed by a Canadian corporation or a Russian one. Even when the investor is controlled by a state, different perception stems from different places whether a Norwegian Sovereign Wealth Fund (SWF) or a Chinese one and this perception varies depending on the place where the investment is made too. ${ }^{37}$

36 SAUVANT, Karl P. "Driving and Countervailing Forces: A Rebalancing of National FDI Policies". Yearbook on International Investment Law \& Policy, p. 233, 2008.

37 In 2007 Statoil, the Norwegian State Owned Enterprise which happened to be the world's biggest one of this kind, bought North American Oil Sands Corp. (NAOSC) and no special concerns were raised in Canada (Statoil's $\$ 2$ bln Canadian Oil Sands Deal Approved, Reuters (on line), 26 June 2007, <http://uk.reuters.com/article/statoilnaosc-approval-idUKL2668735420070626> accessed 13 December 2017). Whereas two years earlier state owned CNOOC was forced to drop its bid for US based oil producer UNOCAL due to national security concerns and alleged violation of fair trade rules created by this operation (Chinese Drop Bid to Buy U.S. Oil Firm, The Washington Post (on line), 3 May 2005, <http://www.washingtonpost.com/wpdyn/content/article/2005/08/02/AR2005080200404.html>. Ac-

\subsubsection{Origin of the investment}

The origin of the FDI constitutes an essential element in the current security related discourse towards foreign investment. Against whom is protection sought? The primary response to this question is: against certain investors who come from individual countries, those which are perceived as hostile or with which the host country has an unfriendly relationship. ${ }^{38}$

FDI has been traditionally considered "foreign" because of the nationality of the investor. This principle is also present in the vast majority of IIAs that choose nationality as the distinctive element to determine foreignness. ${ }^{39}$ Nevertheless, this rule poses some problems in relation to private individuals and raises many questions as regards corporations. The issue of the origin of FDI may be sometimes rather problematic because it is not always easy to actually verify its real provenance. Not only because of the intrinsic difficulty in determining the nationality of a firm but, also and increasingly, because of the structure of international trade and investments. $^{40}$

\subsubsection{The nature of the investment: Sovereign- -driven investment}

Western developed economies have traditionally been, and are, open to FDI. However, the financial crisis and the appearance of new economic actors worldwide have made them generate a certain degree of prevention as regards FDI or, at least, as regards some FDI; one coming from certain specific countries and/or directed towards certain firms or areas of the economy. The nature of FDI constitutes an additional element of concern and potential control. Many cases of acquisitions of existing firms by some SWFs and, mostly by, State Owned Enterprises (SOEs) ${ }^{41}$ since the beginning

cess on: 29 Nov. 2017.

38 Note UNCTAD. The Protection of National Security in IIAs. UNCTAD Series on International Investment Policies for Development. New York/Geneva: UNCTAD/DIAE/IA/2008/5, UNCTAD, 2009. p. 17.

39 DIMOPOULOS, Angelos. EU Foreign Investment Law. Oxford: OUP, 2011. p. 22; DOLZER, Rudolf; SCHREUER, Christoph. Principles of International Investment Law. 2 ed. Oxford: OUP, 2012. p. 32. 40 DIMOPOULOS, Angelos. EU Foreign Investment Law. Oxford: OUP, 2011. p. 33-6.

41 GILLIGAN, George; BOWMAN, Megan; O’BRIEN, Justin. The Global Impact of State Capital, The University of New South Wales School of Law, Centre for Law, Markets and Regulation, 
of the financial crisis in 2007 have been published. ${ }^{42}$ This growing role played by SWFs and SOEs in recent times, and the wide potential for influence over their objectives and activities by foreign governments directly or indirectly owning or controlling them, has created certain concerns in host states regarding the real purpose of the investment to be made: whether it is purely commercial or it primarily responds to some political and geo-strategic reasons.

The increase of FDI, especially in the form of M\&As coming from emergent economies, of different political ideologies, geographical regions or levels of development, generates doubts about the current internal structure and management standards of these SCEs, and also as regards the implementation of their activities in accordance with the basic rules of fair competition and free economy in so far as they may, for instance, have access to funding by state-owned financial institutions at a lower rate of return on their invested capital than private investors, ${ }^{43}$ thus impairing free competition in the global market.

This move comes together with a change in the pattern of its development that may also affect its future. M\&A has now become the dominant form of FDI and FDI by private equity and hedge funds, as well as SCEs, mainly SWFs and SOEs is gaining relevance. ${ }^{44}$ In addition to the origin, foreign investors who are owned or controlled by foreign states constitute an autonomous category of investors that are considered as such in many countries irrespective of their nationality or of the target of the particular FDI project. ${ }^{45}$

CLMR Research paper series, Working Paper, n. 13-2, Sydney, July 2013. p. 16.

42 Note JOST, Thomas. "Sovereign Wealth Funds and the German Reaction". In: SAUVANT, Karl P.; SACHS, Lisa E. SCHMIT JONGBLOED, Wouter P.F. (Ed.). Sovereign Investment. Oxford: Concerns and Policy Reactions, OUP, 2012. p. 453.

43 Note GÖKGÜR, Nilgün. "Are Resurging State-Owned Enterprises Impeding Competition Overseas?”. In: SAUVANT, Karl P.; REIMER, Jennifer. (Ed.). FDI Perspectives: Issues in International Investment. 2. ed. New York: VCC, 2012. p. 26.

44 SAFARIAN, A. Edward, "The Canadian Policy Response to Sovereign Direct Investment”. In: SAUVANT, Karl P.; SACHS, Lisa E.; SCHMIT JONGBLOED, Wouter P. F. (Ed.). Sovereign Investment. Oxford: Concerns and Policy Reactions, OUP, 2012. p. 431.

45 These actors are the consequence of the process of globalization undergone by the economy as well as a reflection of the more proactive "state-led investment capitalism" that characterizes the global economy nowadays. See, GILLIGAN, George; BOWMAN, Megan; O'BRIEN, Justin. The Global Impact of State Capital, The University of New South Wales School of Law, Centre for Law, Markets and Regulation, CLMR Research paper series, Working $\mathrm{Pa}$ -
The global threat perception has increased steadily in the last few years and national security concerns are affecting the development of international trade and of FDI. This becomes especially manifest as regards the protection of certain strategic industries and of some critical infrastructures. ${ }^{46}$ The changing origin of FDI and the possibility of certain areas of the economy to be dominated by foreigners have raised national security anxieties in many western economies as well as have fostered economic nationalism. ${ }^{47}$ This dissatisfaction increases in relation to sovereign driven FDI.

For instance, sovereign driven foreign investment has constituted a hot topic for a long time in Australia. Already in 2009, the Australian Senate Economics References Committee launched a public enquiry on SOEs and afterwards issued a Report which got a response from the Government at the end of that year. ${ }^{48}$ The Senate welcomed and praised works undertaken by certain international organisations in order to regulate SOEs but added that the Committee "believes that the best way for Australia to regulate the conduct of foreign investors (be they SWF, SOE or private commercial operator), is through developing robust domestic legislation". ${ }^{49}$ Nevertheless, the Senate finally considered that the Australian regulatory framework was sufficient..$^{50}$ Australia finally modified its regulation in 2008 to include a new policy on sovereign FDI. Currently, the process of evaluation of FDI proposals in Australia is made directly dependent on the nature of

per, Sydney n. 13-2, July 2013. p. 12.

46 UNITED NATIONS CONFERENCE ON TRADE AND DEVELOPEMENT. The Protection of National Security in ILAs. UNCTAD Series on International Investment Policies for Development. New York/Geneva: UNCTAD/DIAE/IA/2008/5, UNCTAD, 2009. p. 14.

47 MALAWER, Stuart S. "Global Mergers and National Security”. Virginia Lanyer Magazine, p. 33-34, Dec. 2006.

48 Several parliamentary reviews of the FDI review system have taken place during the last few years, noted GOLDING, Greg. "Australia's Experience with Foreign Direct Investment by State Controlled Entities: A Move towards Xenophobia or Greater Openness?" Seattle University Law Review, v. 37, p. 533-546, 2014.

49 THE SENATE, ECONOMIC REFERENCES COMMITTEE. Foreign investment by state-owned entities. Canberra, September 2009. Available in: <http://www.aph.gov.au/Parliamentary_Business/ Committees/Senate/Economics/Completed_inquiries/2008-10/ firb_09/report/index>. Access on: 15 Jul. 2018.

50 THE SENATE, ECONOMIC REFERENCES COMMITTEE. Foreign investment by state-owned entities. Canberra, September 2009. Available in: <http://www.aph.gov.au/Parliamentary_Business/ Committees/Senate/Economics/Completed_inquiries/2008-10/ firb_09/report/index >. Access on: 15 Jul. 2018. 
the foreign investor. Any investment proposal made by state-owned or controlled foreign corporations aimed at acquiring a direct interest in Australia -usually 10 per cent or the ability to influence, participate in or control it-, to initiate a new business or gaining an interest in Australian land are always subject to scrutiny and prior acceptance by the administration, regardless of the value of the investment. ${ }^{51}$ Other reforms in this same sense have taken place around the world. ${ }^{52}$

SWFs and SOEs are state-controlled investors with enormous amounts of capital available and with a dual personality as public actors performing, at least in theory, private activities with not always clearly private -in the sense of purely commercial- objectives. SOEs and SWFs do not constitute new realities in the economy nor in the FDI arena. ${ }^{53} \mathrm{SWF}$ and SOEs have existed for some decades but they have gained major relevance in the last twenty years generating mixed attitudes towards them. The active role that they have played in the world economy has raised concerns regarding the nature of their activity and their potential control of, and influence on, key sectors of the economy, mostly in developed countries. ${ }^{54}$ It is considered that not all coun-

51 THE TREASURER. Australia's Foreign Investment Policy Our Approach. July 1st, 2016. Available in: <https://firb.gov.au/ files/2015/09/Australias-Foreign-Investment-Policy-2016-2017. pdf $>$. Access on: 15 Jul. 2018. 5. Additionally, some exceptions that apply to non-government foreign investors are not applicable to foreign government investors. Specific exemptions for foreign government investors include, for instance, the acquisition of residential land to be used for diplomatic purposes (Ibid, 6). Note also GOLDING, Greg. "Australia's Experience with Foreign Direct Investment by State Controlled Entities: A Move towards Xenophobia or Greater Openness?" Seattle University Law Review, v. 37, p. 552, 2014.

52 MUCHLINSKI, Peter T. Multinational Enterprises \& the Law. 2 ed. Oxford: OUP, 2007. p. 201.

53 Resemblance to the British East India Company, the Hudson Bay Company or the Dutch East India United Company, founded during XVII Century have been stressed. Note GILLIGAN, George; BOWMAN, Megan; O'BRIEN, Justin. The Global Impact of State Capital, The University of New South Wales School of Law, Centre for Law, Markets and Regulation, CLMR Research paper series, Working Paper No. 13-2, Sydney, July 2013. p. 10.

54 Nevertheless, SWFs enjoyed a sudden upgrade in their reputation in the period between March 2007 and June 2008 when SWFs injected US $\$ 59$ billion into western financial institutions, including high-profile equity purchases of Barclays, Citigroup Inc., Credit Suisse, Merrill Lynch, Morgan Stanley or UBS. In fact, in 2007 a bunch of SWFs owned by Singapore, Kuwait or South Korea, 2007 provided much of the US\$21 billion needed by Merrill Lynch and Citicorp to avoid bankruptcy, note DREZNER, Daniel W. "Sovereign Wealth Funds and the (In)security of Global Finance". Fall/Winter Journal of International Affairs, v. 62, p. 115, 2008; PISTOR, Katharina. "Sovereign Wealth Funds and Global Finance". In: SAUVANT, tries share the same values and behaviour and that their companies may act in accordance with political or ideological ideas and not only on a purely commercial basis. Host countries are eager to receive FDI but they fear their non-commercial use and want to protect themselves against this potential use and the consequences for their national security or their economy arising out of it.

Emerging economies have traditionally invested their surplus of foreign exchange reserves in low-risk assets such as US Treasury notes. ${ }^{55}$ However the growth of surpluses in certain economies during the last two decades has fuelled a shift of excess reserves to higher-risk operations aimed to facilitate the diversification of accumulated reserves and to gain a higher-return investment. ${ }^{56}$ SCEs are nowadays broadening their investment worldwide affecting highly sensitive industries and economic areas of host states such as energy and mining, network technology, critical infrastructures management or banking and finance, in which, additionally, some national champion industries of the host state may be involved. ${ }^{57}$

\subsubsection{The target of the investment}

In addition to the origin and/or the nature of the investment, the particular sector where it is to be made

Karl P.; SACHS, Lisa E.; SCHMIT Jongbloed, Wouter P. F. (Ed.). Sovereign Investment. Oxford: Concerns and Policy Reactions, OUP, 2012. p. 145; WEISS, Martin A. Sovereign Wealth Funds: Background and Policy Issues for Congress. CRS Report for Congress, Congressional Research Service, RL34336, Washington 3 September 2008. p. 1-2; GILSON, Ronald; MILHAUPT, Curtis. "Sovereign Wealth funds and Corporate Governance: A Minimalist Response to the New Merchantilism". Standford Law Review, v. 60, p. 1345-1348, 2008. Nevertheless, the participation of SWF, many from emergent countries in global financial players has existed since long.

55 GILSON, Ronald; MILHAUPT, Curtis. "Sovereign Wealth funds and Corporate Governance: A Minimalist Response to the New Merchantilism". Standford Law Review, v. 60, p. 1347, 2008; ROSE, Paul. "Sovereigns as Shareholders". North Carolina Law Review, v. 87, p. 101-105, 2008.

56 WEISS, Martin A. Sovereign Wealth Funds: Backeground and Policy Issues for Congress. CRS Report for Congress, Congressional Research Service, RL34336, Washington 3 September 2008. p. 2; GILSON, Ronald; MILHAUPT, Curtis. "Sovereign Wealth funds and Corporate Governance: A Minimalist Response to the New Merchantilism". Standford Law Review, v. 60, p. 1348, 2008. This is not a new reality because the same happened with Japan during the late 1980's, note ROSE, Paul. "Sovereigns as Shareholders". North Carolina Law Review, v. 87, p. 102, 2008.

57 GILSON, Ronald; MILHAUPT, Curtis. "Sovereign Wealth funds and Corporate Governance: A Minimalist Response to the New Merchantilism”. Standford Law Review, v. 60, p. 1348, 2008. 
or the specific firm targeted constitute a landmark for the evaluation and acceptance of FDI proposals. For different reasons, the host country may wish to retain control over certain key areas of its economy or to prevent "flagship" companies falling under the control of foreigners, even if they come from friendly countries. ${ }^{58}$

The determination of these specific sectors and fir$\mathrm{ms}$ underlie the increasing introduction of screening systems on national security and related grounds in some countries of the world. In 2005 France identified certain sectors where FDI would be subject to review, ${ }^{59}$ in 2007, the US increased the number of transactions subject to revision by the Committee on Foreign Investment in the US (CFIUS), ${ }^{60}$ also in 2009 Canada and Germany introduced all-sectors national security review mechanisms. ${ }^{61}$ In Australia, special attention is devoted to foreign investment in land, ${ }^{62}$ a highly critical sector for Australian economy and the "nation's psyche". ${ }^{63}$

58 UNCTAD. The Protection of National Security in ILAs. UNCTAD Series on International Investment Policies for Development. New York/Geneva: UNCTAD/DIAE/IA/2008/5, UNCTAD, 2009. p. 18.

59 Décret $n^{\circ}$ 2005-1739 du 30 décembre 2005 réglementant les relations financières avec l'étranger et portant application de l'article L. 151-3 du code monétaire et financier [Decree No 2005-1739 of 30 governing foreign financial relationships and applying article L. 151-3 of the Monetary and Financial Code] (France) JO, 31 December 2005. Note also, Décret n 2014-479 du 14 mai 2014 relatif aux investissements étrangers soumis à autorisation préalable [Decree No 2014-479 of 14 May 2014 on foreign investment submitted to premiliminary registration] (France) JO, 15 May 2014 and Décret $n^{\circ}$ 2017-932 du 10 mai 2017 portant diverses mesures de simplification pour les entreprises [Decree No 2017-932 of 10 May 2017 on measures of simplification for enterprises] (France) JO, 11 May 2017.

60 Foreign Investment and National Security Act of 2007 (FINSA), Pub.L. 110-49, 121 Stat. 246.

61 Respectively, Investment Canada Act (ICA) R.S.C. 1985, c. 28 (1st Supp.), Part IV.1 and Außenwirtschaftsgesetz [Foreign Trade and Payments Act] (Germany) 6 June 2013, BGBl I, 1482, reformed by the Neunte Verordnung zur Änderung der Außenwirtschaftsverordnung [Ninth Ordinance amending the AWV] (Germany) 14 July 2017, BAnz AT 17 July 2017 V1.

62 In accordance with S. 4 of the Foreign Acquisitions and Takeovers Act 1975 ('FATA'), Act No. 92 of 1975, s 4, Australian land "means agricultural land, commercial land, residential land or a mining or production tenement". Note THE TREASURER. Australia's Foreign Investment Policy Our Approach. July 1st, 2016. Available in: <https://firb.gov.au/files/2015/09/Australias-Foreign-Investment-Policy-2016-2017.pdf>. Access on: 15 Jul. 2018. Annex 1, 15. 63 SANYAL, Kali. Foreign investment in Australian agriculture, Parliament of Australia. Department of Parliamentary Services, Research Paper, Parliament of Australia, Canberra 18 February 2014. 15; GILLIGAN, George; BOWMAN, Megan; O'BRIEN, Justin. The Global Impact of State Capital, The University of New South Wales School of Law, Centre for Law, Markets and Regulation, CLMR Research paper series, Working Paper No. 13-2, Sydney, July 2013. p.
Australian land includes "agricultural and commercial land, mining and production tenements, and residential land". ${ }^{64}$ In relation to agricultural land ${ }^{65}$ the threshold for evaluation was reduced drastically in March 2015 from AUD252 million to AUD15 million. ${ }^{66}$ But, as a general rule all foreign persons acquiring vacant commercial land ${ }^{67}$ or an interest in residential real estate ${ }^{68}$ must obtain approval regardless of its value. ${ }^{69}$ As a matter of principle, services tend to be more restricted than manufacturing as regards the acceptance of FDI. ${ }^{70}$ In many cases services

66. Significantly, a vast majority of Australians are favorable to FDI but rising opposition exists - 63 per cent in 2014- as regards foreign investment in agriculture, as well as in ports and airports. OLIVER, Alex. The Lowy Institute Poll 2014. Lowy Institute for International Policy. Sydney, 2014. Available in: <https://www.lowyinstitute.org/ sites/default/files/2014_lowy_institute_poll_0.pdf>. Access on: 15 Jul. 2018. 3-4 \& 11.

64 In accordance to the Australia's Foreign Investment Policy 2016 (<https://firb.gov.au/files/2015/09/Australias-ForeignInvestment-Policy-2016-2017.pdf> accessed 29 November 2017). Note, The Treasurer, above n 51, 4.

65 In accordance to s 4 'FATA', agricultural land means, "land in Australia that is used, or that could reasonably be used, for a primary production business."

66 Note THE TREASURER. Australia's Foreign Investment Policy Our Approach. July 1st, 2016. Available in: <https://firb.gov.au/ files/2015/09/Australias-Foreign-Investment-Policy-2016-2017. pdf>. Access on: 15 Jul. 2018. p. 4, regarding the threshold for investors coming from Chile, New Zealand and the US. This move is in line with the large opposition -81 per cent in 2012- against the Australian government allowing foreign companies to buy Australian farmland to grow crops or farm livestock (and 63 per cent saying they are strongly against), see HANSON, Fergus. Australia and New Zealand in the World Public Opinion and Foreign Policy. Lowy Institute for International Policy. Sydney. 2012. Available in: < https://www. lowyinstitute.org/publications/lowy-institute-poll-2012-publicopinion-and-foreign-policy>. Access on: 14 Jul. 2018.

67 In accordance to s 4 'FATA', this notion means "land in Australia or the seabed of the offshore area, other than land: (a) used wholly and exclusively for a primary production business; or (b) on which there is at least one dwelling (except commercial residential premises); or (c) on which the number of dwellings (except commercial residential premises) that could reasonably be built is less than the number prescribed by the regulations for the purposes of subparagraph (a)(ii) of the definition of residential land in this section."

68 In accordance to s 4 'FATA', residential land "(a) means land in Australia if: (i) there is at least one dwelling on the land; or (ii) the number of dwellings that could reasonably be built on the land is less than the number prescribed by the regulations; and (b) does not include land: (i) used wholly and exclusively for a primary production business; or (ii) on which the only dwellings are commercial residential premises."

69 This rule is subject to international commitments acquired by Australia, note THE TREASURER. Australia's Foreign Investment Policy Our Approach. July 1st, 2016. Available in: <https://firb.gov.au/ files/2015/09/Australias-Foreign-Investment-Policy-2016-2017. pdf>. Access on: 15 Jul. 2018. p. 4.

70 GOLUB, Stephen S. Measures of Restrictions on Inward Foreign Di- 
are considered strategic or sensitive for the country, therefore the discrimination that may exist against foreign ownership is not based, or at least is not only based, on economic or commercial reasons but also on national security or national essential security interests grounds and, in certain cases, on economic nationalism or protectionist ideas. $^{71}$

\subsubsection{Thresholds}

In addition to the origin or nature of the foreign investment and to the target of the investment, also the amount of the investment or the future degree of involvement of the foreign investor in a specific firm is relevant. Thresholds for invoking national security concerns are usual fixed in some FDI review systems on national security grounds. It is important to specify how much involvement a foreign investor must have in a specific firm in the host state before it is considered to be a risk for its national security. If it is necessary for the foreign investor to fully own the firm in order to become a risk for the host state or whether it is enough when an effective control or just certain voting rights exist, and how this is actually determined. All these elements are for states to determine and different responses to them are found worldwide. ${ }^{72}$ For instance, in Australia, as a general rule, and in relation to non-land proposals, ${ }^{73}$ foreign entities ${ }^{74}$ must notify, and get acceptance, before

rect Investment for OECD Countries. Paris: OECD Economic Department Working Papers, 2003. p. 16. (No. 357, OECD Publishing).

71 GOLUB, Stepehn S. "Opennes to Foreign Direct Investment in Services: An International Comparative Analysis". The World Economy, p. 1245, 2009. p. 1245, 1246.

72 UNITED NATIONS CONFERENCE ON TRADE AND DEVELOPEMENT. The Protection of National Security in ILAs. UNCTAD Series on International Investment Policies for Development. New York/Geneva: UNCTAD/DIAE/IA/2008/5, UNCTAD, 2009. p. 24-5.

73 This threshold is elevated to AUD1 094 million for investors coming from Chile, Japan, South Korea, New Zealand and the US, when the investment is made in non-prescribed sensitive sectors. The usual threshold of AUD252 million remains when the investment is made in prescribed sensitive sectors in accordance with s 26 'FATA'. See THE TREASURER. Australia's Foreign Investment Policy Our Approach. July 1st, 2016. Available in: <https://firb.gov.au/ files/2015/09/Australias-Foreign-Investment-Policy-2016-2017. pdf $>$. Access on: 15 Jul. 2018. p. 3.

74 Note s 4 'FATA' as regards the meaning of 'foreign person': (a) an individual not ordinarily resident in Australia; or (b) a corporation in which an individual not ordinarily resident in Australia, a foreign corporation or a foreign government holds a substantial interest; or (c) a corporation in which 2 or more persons, each of whom is an individual not ordinarily resident in Australia, a foreign acquiring a substantial interest -at least 20 per cent ${ }^{75}$ in, or the control of, an Australian business valued AUD252 million or more. ${ }^{76}$ To enter into such an acquisition without giving prior notification and obtaining a statement of approval by the government constitutes an offence. ${ }^{77}$

\section{Mechanisms to control FDI eX ante on NATIONAL SECURITY OR RELATED GROUNDS}

Acquisitions of national corporations by foreign investors either private or public coming on many occasions from emerging markets and targeted at different sectors of the economy or firms of the host state has spread social alarm and regulatory reactions against FDI in many places of the world, or at least against FDI coming from certain countries or that which is targeting certain areas of the national economy. This refers to developing countries - the extractive industry is a good example of that- but also increasingly to developed ones. Developed countries fear they will lose control of strategic sectors of the economy and national cham-

corporation or a foreign government, hold an aggregate substantial interest; or (d) the trustee of a trust in which an individual not ordinarily resident in Australia, a foreign corporation or a foreign government holds a substantial interest; or (e) the trustee of a trust in which 2 or more persons, each of whom is an individual not ordinarily resident in Australia, a foreign corporation or a foreign government, hold an aggregate substantial interest; or (f) a foreign government; or (g) any other person, or any other person that meets the conditions, prescribed by the regulations.' See THE TREASURER. Australia's Foreign Investment Policy Our Approach. July 1st, 2016. Available in: <https://firb.gov.au/files/2015/09/Australias-ForeignInvestment-Policy-2016-2017.pdf>. Access on: 15 Jul. 2018. p. 3.

75 That is, in those cases when a single person has 20 per cent or more, or several foreign persons have 40 per cent or more, of the issued shares, issued shares if all rights were converted, voting power, or potential voting power, of a corporation. THE TREASURER. Australia's Foreign Investment Policy Our Approach. July 1st, 2016. Available in: <https://firb.gov.au/files/2015/09/Australias-ForeignInvestment-Policy-2016-2017.pdf>. Access on: 15 Jul. 2018. p. 3 \& s 4 'FATA'. Regarding the way to calculate this participation, note Golding, above n 48, 547.

76 Some exemptions from the need to seek foreign investment approval are foreseen in certain circumstances, note THE TREASURER. Australia's Foreign Investment Policy Our Approach. July 1st, 2016. Available in: <https://firb.gov.au/files/2015/09/AustraliasForeign-Investment-Policy-2016-2017.pdf>. Access on: 15 Jul. 2018. p. 6.

77 GOLDING, Greg. “Australia’s Experience with Foreign Direct Investment by State Controlled Entities: A Move towards Xenophobia or Greater Openness?” Seattle University Law Review, v. 37, p. $547,2014$. 
pions in favour of foreign corporations coming in many cases from geopolitical or economic competitors. ${ }^{78}$

In this scenario it is indispensable to distinguish between the protection of the state and its economic and social viability, through the reference to terms like national security or essential security interests and the protection of the economic interests of the state, of its economic development or any other critical objective which may or may not be linked to the previous idea of national security and that in certain cases may even run against the notion of the free market. The line between protecting legitimate public policy objectives and protectionism is very fine and not always easy to be determined. ${ }^{79}$

The study of FDI has been traditionally very much linked to the analysis of IIAs, especially of Bilateral Investment Treaties (BITs) and, consequently, to the dimension of its protection expost, once the specific investment project has already been implemented in the host country. Only some isolated BITs, mostly those entered into by the US and Canada and more recently Japan, ${ }^{80}$ cover both the pre-establishment and the post-establishment phase of FDI. ${ }^{81}$ Habitually, the majority of them, irrespective of their bilateral and multilateral dimension, basically include rules referring to the traditional dimension of the promotion and protection of FDI. $^{82}$

Nevertheless, this traditional expost approach linked to the IIAs entered into worldwide is now combined in

78 SAUVANT, Karl P. "Driving and Countervailing Forces: A Rebalancing of National FDI Policies". Yearbook on International Investment Law \& Policy, p. 240-243, 2008.

79 Additionally, the "fuzziness" of the terms used "inevitably" creates the risk of abuse for protectionist purposes. SAUVANT, Karl P. FDI Protectionism Is on the Rise, Policy Research Working Paper 5052, The World Bank Poverty Reduction and Economic Management Network, International Trade Department World Bank, Washington, September 2009. p. 14.

80 Consider, MUCHLINSKI, Peter T. "Corporations and the Uses of Law: International Investment Arbitration as a "Multilateral Legal Order". Oñati Socio-Legal Series, v. 1, n. 4, p. 3, 2011. p. 3-4.

81 Also the OECD Code of Liberalization of Capital Movements (OECD, Paris, 2013) and the OECD Code of Current Invisibles Operations (OECD, Paris, 2013) consider the pre-establishment phase, note YANNACA-SMALL, Katia, Essential Security Interests under International Investment Law, in: OECD. International Investment Perspectives: Freedom of Investment in a Changing World, Paris: OECD, 2007. p. 94.

82 Note TRAKMAN, Leon E.; RANIERI, Nicola W. "Foreign Direct Investment: A Historical Perspective". In: TRAKMAN, Leon E.; RANIERI, Nicola W. (Ed.). Regionalism in International Investment Law. Oxford: OUP, 2013. p. 19. many states with an increased focus on the phase previous to the actual implementation of the investment in the host country. The goal to balance the commitment towards the free circulation of FDI with the preservation of certain areas of the national economy and fir$\mathrm{ms}$ from control by foreign investors has not -always or only- given place to broader areas where access of FDI is not allowed, but to the establishment of mechanisms aimed to control ex ante foreign investment in certain fields or coming from certain countries on national security or national interests' bases. ${ }^{83}$ Some countries have now introduced changes in their legislations on FDI. And some of these changes relate to the introduction of control systems on the entry of FDI into their economies. ${ }^{84}$ The final consequence is that the state is granted the power to regulate and to stop some FDI proposals, at least those that, according to it, pose national security concerns. ${ }^{85}$

Despite the generally positive attitude maintained as regards FDI flows a truly "open door policy" towards foreign investment does not seem to exist, or to have ever existed, anywhere. No country accepts foreign capital, irrespective of its origin, to enter its economy with total freedom and to be freely invested in any area of the country. ${ }^{86}$ In fact when UNCTAD analysed the legislative changes on FDI implemented between 1990 and 2009 it stressed the incidence of the promotion and liberalization of FDI during this period: between 1992 and 2009 UNCTAD reported 2748 legislative changes worldwide with 89 per cent favouring FDI. ${ }^{87}$ However,

83 This has fostered for instance the establishment of screening systems of FDI projects on national security or related grounds in many countries of the world. See, SAUVANT, Karl P. "Is the United States Ready for FDI from China? Overview". In: SAUVANT, Karl P. (Ed.). Investing in the United States Is the US Ready for FDI from China, Studies in International Investment. Edward Elgar: Cheltenham/Northampton, 2009. p. 10.

84 As well as, significantly, to the promotion and incentives of FDI, note SUMNER, Andrew. "Foreign Direct Investment in Developing Countries: Have We Reached a Policy 'Tipping Point'?". Third World Quarterly, v. 29, n. 2, p. 239-242, 2008.

85 VANDUZER, J. Anthony; SIMONS, Penelope; MAYEDA, Graham. Integrating Sustainable Development into International Investment Agreements: A Guide for Developing Countries (prepared for the Commonwealth Secretariat by the authors, London, 2012. p. 39-224; UNCTAD. Investment Policy Framework for Sustainable Development, Doc. Geneva: UNCTAD/DIAE/PCB/2015/5, UNCTAD, 2015. p. 8.

86 SALACUSE, Jeswald W. The Three Laws of International Investment. National, Contractual and International Frameworks for Foreign Capital. Oxford: OUP, 2013. p. 87.

87 UNITED NATIONS CONFERENCE ON TRADE AND DEVELOPEMENT. World Investment Report 2010. Investing in a 
and despite the maintenance of this global trend in favour of the liberalization of FDI, many of these national regulations that include provisions aimed to enhance the entrance of FDI and which usually grant investors many benefits and guarantees, now increasingly vest at the same time in host states the possibility to control FDI and to prevent it from entering their economy or some firms on certain different grounds.

Most states have retained the power to control and prevent international M\&As under national law and, in many cases, also in accordance with international agreements entered into by them. Limits to FDI in certain specific sectors like the military or infrastructures or general references to national security or public policy are introduced into their regulations in different ways ${ }^{88}$ In some cases the final consequence is that the investment policy of the country and its investment law are becoming increasingly considered and treated as an additional tool to foster national security policies amid an increasingly securitized world. ${ }^{89}$ In fact, the OECD already stated in 2006 that "(I)ssues of security and other strategic concerns have moved to the forefront of domestic and international investment policy making", 90 and recently warned of the rise of "hidden protectionism" and protectionism abuse based, among other factors, on national security and related grounds. ${ }^{91}$

No specific rules controlling the entrance of foreign investment on national security, national essential security interests and related grounds existed for a long time in many countries. ${ }^{92}$ But this has changed in the last few decades and now more and more specific rules on FDI govern this issue in many countries. States are

Low-Carbon Economy. New York and Geneva: United Nations, 2010. p. 76-7.

88 CHAISSE, Julien; CHAKBABORTY, Debashis; MUKHERJEE, Jaydeep, "Emerging Sovereign Wealth Funds in the Making: Assessing the Economic Feasibility and Regulatory Strategies". Journal of World Trade, v. 45, n. 4, p. 837-854, 2011.

89 ORGANISATION FOR ECONOMIC CO-OPERATION AND DEVELOPEMENT. Protection of "Critical Infrastructure" and the Role of Investment Policies Relating to National Security. Paris: OECD, 2008. p. 9.

90 ORGANISATION FOR ECONOMIC CO-OPERATION AND DEVELOPEMENT. International Investment Perspectives. Paris: OECD, 2006. p. 32.

91 ORGANISATION FOR ECONOMIC CO-OPERATION AND DEVELOPEMENT. Roundtable on Freedom of Investment 20 (19 March 2014) Summary of Roundtable discussions by the OECD Secretariat. Paris: OECD, 2014. p. 9.

92 SORNARAJAH, Muthucumaraswamy. The International Law on Foreign Investment. 3 ed. Cambridge: CUP, 2010, p. 97. nowadays fully concerned about the problems that FDI may cause to them in some cases and special relevance is being given to sovereign FDI. Even countries that are investing abroad are progressively aware of the national security aspects of FDI. Governments are increasingly eager to screen, and in some cases even restrict, condition or block foreign investment implemented through takeovers of already existing domestic corporations on grounds of national security or related grounds. FDI is still wanted and encouraged as a general rule, and policies in favour of attracting FDI are implemented almost worldwide. But this fact does not supersede the increasing desire of many states to preserve certain areas of their economies or firms from foreign control or, in a less invasive way, to control certain FDI of a particular nature -basically sovereign driven FDI-, coming from certain countries or targeting particular firms or sectors of the national economy.

According to the World Bank's Survey Investing Across Borders in 2010, a fifth of the 87 countries analysed require foreign companies to go through a foreign investment approval process before proceeding with investment in certain areas of their economy. And almost 90 per cent limit foreign companies' ability to participate in some specific sectors of their economies, with stricter limits to their participation in services. ${ }^{93}$ Different measures may be adopted by the host state to protect itself -ex ante- from foreign investment on national security or similar grounds. ${ }^{94}$

\subsection{Market access measures}

Prohibiting, fully or partially, foreign investment in particularly sensitive sectors is the most obvious $e x$ ante restriction to FDI. National governments may foresee exclusive national ownership in certain sectors that are considered strategic on different grounds and therefore ban FDI in several areas of the economy. ${ }^{95}$

93 INVESTMENT CLIMATE ADVISORY SERVICES WORLD BANK GROUP. Investing Across Borders 2010. Indicators of foreign direct investment regulation in 87 economies. Washington: World Bank, 2010. p. 8.

94 For instance, imposition of other emergency measures, forced disinvestment, denial of benefits based on the existence of a clause in the agreement, see UNCTAD. The Protection of National Security in ILAs. New York/Geneva: UNCTAD Series on International Investment Policies for Development, UNCTAD/DIAE/IA/2008/5, 2009. p. 30-3.

95 See POLLAN, Thomas. Legal Framework for the Admission of FDI. Utrecht: Eleven International Publishing, 2006. p. 58-61. 
The state has the right to protect its "essential security interests", ${ }^{96}$ and practice shows that the "most heavily restricted sectors" are those considered "highly sensitive to national security or national sovereignty considerations". ${ }^{97}$ However, a total ban of FDI is almost unrealistic nowadays. Habitually, the prohibition refers to certain specific areas of the economy or industries and affects both developed and developing countries. ${ }^{98}$ In fact, this limited prohibition constitutes a rather habitual measure usually drafted "in grandiose, but vague terms". 99

Full or partial foreign ownership restrictions usually exist in the defence industry (both production of weapons and war materials); air and maritime cabotage services and air traffic control or the purchase of real estate by foreigners in border areas or near other sensitive sites. ${ }^{100}$ Border restrictions, for instance, constitute the most obvious example of limitation of ownership which has existed for a long time in many countries of the world. Foreigners are prevented -or face limitations- from owing real estate near territorial borders or in areas of strategic significance. Additionally restrictions may also concern electricity power grids and exchanges, seaport or airport management, or oil and gas extraction activities. ${ }^{101}$ However, these potential restrictions may have different degrees.

The reservation of certain specific sectors from FDI has been used by developing countries to protect some indigenous industries from foreign control, on the basis of arguments like the 'infant industry' and 'crowding

96 JACKSON, James K. Foreign Investment and National Security: Economic Considerations, Congressional Research Service, 7-5700, RL34561, Washington, 4 April 2013. p. 6.

97 GOLUB, Stephen S. Measures of Restrictions on Inward Foreign Direct Investment for OECD Countries. Paris: OECD Economic Department Working Papers, 2003. p. 24). (No. 357, OECD Publishing).

98 KURTZ, Jürgen. "A General Investment Agreement in the WTO? Lessons from Chapter 11 of NAFTA and the OECD Multilateral Agreement on Investment". University of Pennsylvania Journal of International Economic Law, v. 243, n. 3, p. 713, 2002.

99 SALACUSE, Jeswald W. The Three Laws of International Investment. National, Contractual and International Frameworks for Foreign Capital. Oxford: OUP, 2013. p. 94. See also, MUCHLINSKI, Peter T. Multinational Enterprises \& the Law. 2nd ed. Oxford: OUP, 2007. p. 179-180.

100 UNITED NATIONS CONFERENCE ON TRADE AND DEVELOPMENT. World Investment Report 2016. Investor Nationality: Policy Challenges. New York and Geneva: United Nations, 2016. p. 97-8.

101 UNITED NATIONS CONFERENCE ON TRADE DEVELOPMENT. World Investment Report 2016. Investor Nationality: Policy Challenges. New York and Geneva: United Nations, 2016. p. 98. out'. ${ }^{102}$ Nevertheless, also developed countries include these sorts of restrictions in certain key network sectors such as energy and transport. The OECD, in 2008, considered transport to be the sector with the highest number of discriminatory measures. ${ }^{103}$ The different discriminatory measures adopted by the several members of the OECD, their broadness and specific targets, render a final map with many differences among countries as regards the admission of FDI in sectors of the economy and infrastructures considered critical. ${ }^{104}$ These differences increase further when the FDI proposal is made by corporations controlled or owned by foreign countries. The sectoral pattern of restrictions tends to be rather similar in both advanced and emerging economies. However, the degree of restrictiveness is generally higher in the latter group of countries. ${ }^{105}$ In some cases no explicit rule exists and a more subtle position is maintained. ${ }^{106}$

In addition to this ban, either total or sectoral, of foreign ownership in certain areas of the economy, also the number of foreign investors admitted into a certain sector of the economy can be limited by certain states. $^{107}$

\subsection{Maintenance of state's monopolies}

Another way of preserving some strategic sectors of the economy from foreign investment is through the

102 MUCHLINSKI, Peter T. Multinational Enterprises of the Law. 2. ed. Oxford: OUP, 2007. p. 183-4.

103 ORGANISATION FOR ECONOMIC CO-OPERATION AND DEVELOPEMENT. Protection of "Critical Infrastructure" and the Role of Investment Policies Relating to National Security. Paris: OECD, 2008. p. 7.

104 A comparative table may be found at OECD. Protection of "Critical Infrastructure" and the Role of Investment Policies Relating to $\mathrm{Na}$ tional Security. Paris: OECD, 2008. p. 10-1.

105 THOMSEN, Stephen; MISTURA, Fernando. Is investment protectionism on the rise? Evidence from the OECD FDI Regulatory Restrictiveness Index OECD Global Forum on International Investment. Paris: OECD, 2017. p. 6.

106 In Canada, for instance, the health care sector is considered to be de facto closed to FDI because private hospitals and clinics may not receive payments from provincial health insurance funds, which are deemed critical for the financial viability of operators in the sector. Vid. INVESTMENT CLIMATE ADVISORY SERVICES WORLD BANK GROUP. Investing Across Borders 2010. Indicators of foreign direct investment regulation in 87 economies. Washington: World Bank, 2010. p. 98.

107 KURTZ, Jürgen. "A General Investment Agreement in the WTO? Lessons from Chapter 11 of NAFTA and the OECD Multilateral Agreement on Investment". University of Pennsylvania Journal of International Economic Law, v. 243, n. 3, p. 725, 2002. 
maintenance of state monopolies in particularly sensitive sectors usually linked to the provision of basic public services and communications in a certain state; railway transport and infrastructure maintenance, landline telecommunications, oil and gas transportation, or electricity and water transmission are usual examples of them. ${ }^{108}$

\subsection{Equity limitation}

In addition to the previous measures some countries have also introduced the requirement of joint ventures or equity restrictions in certain areas of their economy. In fact, it is said to be one of the most common forms of discrimination against foreign investors, although their effectivity is, once again, under question. ${ }^{109}$

The amount and final transcendence of the FDI implemented in the host state can be controlled in order to ensure local control of the sector or firm affected. For example, national governments can limit the share of companies' equity capital in a specific sector that non-residents are allowed to own, ${ }^{110}$ limit FDI to a certain level of voting control in an enterprise in a specific given sector or impose the involvement of local participants, irrespective of their public or private condition, in the FDI project. ${ }^{111}$ For instance, the Open Air Agreement between the EU and USA of 2007 explicitly limits the possibility of foreign ownership, even by an EU citizen or corporation, of US airlines to no more than 25 per cent of the corporation's voting equity. ${ }^{112}$

108 UNITED NATIONS CONFERENCE ON TRADE AND DEVELOPMENT. World Investment Report 2016. Investor Nationality: Policy Challenges. New York and Geneva: United Nations, 2016. p. 98.

109 THOMSEN, Stephen; MISTURA, Fernando. Is investment protectionism on the rise? Evidence from the OECD FDI Regulatory Restrictiveness Index OECD Global Forum on International Investment. Paris: OECD, 2017. p. 4.

110 GOLUB, Stephen S. Measures of Restrictions on Inward Foreign Direct Investment for OECD Countries, OECD. Economic Department Working Papers, No. 357. Paris: OECD Publishing, 2003. p. 7; MUCHLINSKI, Peter T. Multinational Enterprises \& the Law. 2. ed. Oxford: OUP, 2007. p. 184-191.

111 MUCHLINSKI, Peter T. Multinational Enterprises \& the Law. 2. ed. Oxford: OUP, 2007. p. 192-201.

112 REFERENCE "ANNEX 4: Concerning Additional Matters Related to Ownership, Investment and Control. Article 1: Ownership of Airlines of a Party. 1. Ownership by nationals of a Member State or States of the equity of a U.S. airline shall be permitted, subject to two limitations. First, ownership by all foreign nationals of more than 25 percent of a corporation's voting equity is prohibited. Second, actual control of a U.S. airline by foreign nationals is also pro-
Similar limitations in other areas of the economy like banking, natural resources and energy, ${ }^{113}$ nuclear energy and mining and mineral leases or telecommunications exist in many countries of the world. ${ }^{114}$

In some countries the possibility of golden shares to prevent the acquisition of local firms, usually privatized firms, by unwanted foreign investors also exists. ${ }^{115}$ This is a possibility that, for instance, exists in the UK where golden shares exist in certain enterprises. Hence, the British Government has golden shares in BAE Systems, Rolls-Royce or National Air Traffic Services. In fact, the government has exercised its golden share rights to prevent unwanted takeovers in some cases.

hibited. ...". Note also, United States Government Accountability Office, Report to the Committee on Banking, Housing, and Urban Affairs, U.S. Senate, Sovereign Wealth Funds. Laws Limiting Foreign Investment Affect Certain U.S. Assets and Agencies Have Various Enforcement Processes, GAO-09-608 (Washington DC, 05.2009), p. 15 and Appendix II.

113 Note GRAHAM, Edward M.; MARCHICK, David M. U.S. National Security and Foreign Direct Investment Institute for International Economics. Washington, 2006. p. 13-4.

114 In the case of Canada statutory ownership restrictions exist as regards certain sectors of the economy. Basically in the transportation sector -domestic and international air transportation sectors, foreign participation is limited to a maximum share of 49 per cent- and telecommunications -total direct and indirect foreign ownership in the telecommunications sector (fixed-line and mobile/ wireless infrastructure and services) and in the television broadcasting sectors is limited to $46 \square$ per cent-. INVESTMENT CLIMATE ADVISORY SERVICES WORLD BANK GROUP. Investing Across Borders 2010. Indicators of foreign direct investment regulation in 87 economies. Washington: World Bank, 2010. p. 98. Regarding the origins of this limitation, GRAHAM, Edward M.; MARCHICK, David M. U.S. National Security and Foreign Direct Investment Institute for International Economics. Washington, 2006. p. 11-3. In the US no Federal Laws completely prohibit foreign investment in a specific sector. On the contrary they limit and place additional requirements in certain particular sectors as regards foreign investors, like nuclear energy or airline industries (United States Government Accountability Office, Report to the Committee on Banking, Housing, and Urban Affairs, U.S. Senate, Sovereign Wealth Funds. Laws Limiting Foreign Investment Affect Certain U.S. Assets and Agencies Have Various Enforcement Processes, GAO-09-608 (Washington DC, 05.2009), p. 14; CHALAMISH, Efraim. "Global Investment Regulation and Sovereign Funds". Theoretical Inquiries in Law, v. 13, n. 2, p. 645-651, 2012.

115 See POLLAN, Thomas. Legal Framework for the Admission of FDI. Utrecht: Eleven International Publishing, 2006. p. 61-2; HEINEMANN, Andreas. "Government Control of Cross-Border M\&A: Legitimate Regulation or Protectionism? Control of CrossBorder M\&A". Journal of International Economic Law, v. 15, n. 4, p. 852, 2012. 


\subsection{Screening systems of evaluation on national security grounds}

Screening mechanisms of FDI on national security, national essential interests or related grounds are the rising star in this area. Screening and notification procedures constitute mechanisms to control the flux of FDI that are becoming very popular nowadays around the world. Many countries, both developing and developed states, are aware of the need to protect some industries and areas of their economy from certain FDI or FDI coming from certain countries and are progressively referring to this kind of device. ${ }^{116}$ And states are increasingly designing this kind of instruments which provide the host state administration with the ability to evaluate FDI proposals and decide upon their acceptability or rejection.

These mechanisms are based either on the nature of the specific sector where the FDI project is envisaged, on the existence of a certain threshold or on the nature of the investor, among other potential grounds. States are certainly sovereign to control FDI flows in an absolute manner. However, authors cast some doubts as regards the all-embracing scope of this power and subject the validity of these potential measures to the fact that they are adopted on rational grounds. ${ }^{117}$ A case-by-case evaluation of proposed FDI projects by the government of the host country or by a specialized -and, in some cases, independent- body is undertaken with the goal of establishing whether the project is in accordance with the very basic economic or social policies of the host state or runs against its national security.

As a matter of principle, the development of a

116 As regards developing and emerging countries, note MUCHLINSKI, Peter T. Multinational Enterprises \& the Law. 2nd ed. Oxford: OUP, 2007. p. 202-205; MUCHLINSKI, Peter T. "Corporations and the Uses of Law: International Investment Arbitration as a "Multilateral Legal Order”. Oñati Socio-Legal Series, v. 1, n. 4, p. 51, 2011.

117 The screening of foreign investments and the subsequent eventual prohibition on grounds of, for instance, not being beneficial to the economy of the host state would constitute a rational economic ground and therefore not considered to be wrongful. This rationality would also be admitted in those cases in which the discrimination is based on national security grounds, see SORNARAJAH, Muthucumaraswamy. The International Law on Foreign Investment. 3 ed. Cambridge: CUP, 2010. p. 137. screening system does not in many cases hamper the openness of the country that designs it towards FDI. At least most developed countries and many emerging economies are clearly aligned with the free movement of FDI. Nevertheless, as practice shows, these kinds of systems have also in many cases the tangential effect of dissuading potential FDI projects that are abandoned by their promotors after some concerns are expressed by public authorities. ${ }^{118}$

\subsection{Compulsory registration and check and balance mechanisms}

In addition to the previous systems and not always fully independent of them, the host government can also subject the acceptance of the proposal to the meeting of certain specific conditions for its future implementation. These conditions can be independent of the existence of a screening systems or be included in a prospective conditionality agreement reached as a consequence of the evaluation of the FDI project on national security or related grounds.

Through these mechanisms, host states may try to maximise the benefits of FDI or to control FDI flows by imposing on the investor some performance requirements, although their effectiveness is still a controversial issue. ${ }^{119}$ Specific measures can be very different and vary from country to country.

1) States may subject the acceptance of the prospective FDI operation with a previous disclosure of the characteristics and nature of the FDI project to be implemented to a specific government agency. In the US, for instance, foreign investors in agricultural land upon purchase of more than 10 acres of agricultural land must file a disclosure report to the Department of Agriculture. ${ }^{120}$ Also in Australia, under the Register of

118 HEINEMANN, Andreas. "Government Control of CrossBorder M\&A: Legitimate Regulation or Protectionism? Control of Cross-Border M\&A". Journal of International Economic Law, v. 15, n. 4, p. 851, 2012.

119 LONG, Guoquiang. "China's policies on FDI: review and evaluation". In: MORAN, Theodore H.; GRAHAM, Edward M.; BLOMSTRÖM, Magnus. (Ed.). Does foreign direct investment promote development? Washington: (Institute for International Economics, 2005. p. 315.

120 United States Government Accountability Office, Report to the Committee on Banking, Housing, and Urban Affairs, U.S. Senate, Sovereign Wealth Funds. Laws Limiting Foreign Investment Affect Certain U.S. Assets and Agencies Have Various Enforcement Processes, GAO-09-608 (Washington DC, 05.2009), p. 16, 25 and 
Foreign Ownership of Agricultural Land Act 2015, foreign persons (including foreign government investors) holding interests in agricultural land must also register those interests with the Australian Taxation Office, regardless of the value of that land. New interests need to be registered within 30 days. ${ }^{121}$

2) States can also subject FDI proposals to the imposition of certain conditions as regards local collaboration, capitalisation requirements, export targets, local equity or its direction and management: presence and/ or number of nationals or residents in the board of directors, employment of nationals and so on. ${ }^{122}$ National legislations tend to include some check and balance mechanisms aimed to mitigate any potential misconduct by the foreign investor once the investment -performed either by a purely private or a state driven investor- has been implemented. ${ }^{123}$

Thus, certain countries may permit equity investment with no limits as a general rule while restricting future activities to be undertaken by the enterprise in a certain sector. Again in the US these restrictions apply in the sectors of banking, ${ }^{124}$ as well as in relation to defence and aviation and maritime transportation and they are usually drafted on security considerations. ${ }^{125}$ For instance, in the US defence sector, non US citizens and companies under foreign ownership, control, or influence are generally not eligible for access to classified information. Whereas in the transportation sector, for instance, vessels that are more than 25 per cent foreign owned cannot carry cargo or passengers between US Ports. The same limitation applies to aircrafts that are more than 25 per cent foreign owned and that are pro-

Appendix II.

121 THE TREASURER. Australia's Foreign Investment Policy Our Approach. July 1st, 2016. Available in: <https://firb.gov.au/ files/2015/09/Australias-Foreign-Investment-Policy-2016-2017. pdf $>$. Access on: 15 Jul. 2018.

122 GOLUB, Stephen S. Measures of Restrictions on Inward Foreign Direct Investment for OECD Countries, OECD. Economic Department Working Papers, No. 357. Paris: OECD Publishing, 2003. p. 8; SORNARAJAH, Muthucumaraswamy. The International Law on Foreign Investment. 3 ed. Cambridge: CUP, 2010 p. 92-115.

123 CHALAMISH, Efraim. "Global Investment Regulation and Sovereign Funds". Theoretical Inquiries in Law, v. 13, n. 2, p. 653, 2012. 124 Which goes back to 1869. See GRAHAM, Edward M.; MARCHICK, David M. U.S. National Security and Foreign Direct Investment Institute for International Economics. Washington, 2006. p. 14.

125 Most of them go back to World War I, note GRAHAM, Edward M.; MARCHICK, David M. U.S. National Security and Foreign Direct Investment (Institute for International Economics. Washington, 2006. p. $13 \mathrm{ff}$. hibited to transport passengers or cargo between two US cities. ${ }^{126}$ Airlines are considered strategic assets with a potential national security dimension. ${ }^{127}$

Whether these measures are adopted to preserve some sectors of relevant national interests from foreign control in general or from certain investors coming from particular countries or with the hidden goal of safeguarding particular areas of the economy from competition is something to be determined on case by case bases. However, and generally speaking, all those countries endorsing these kinds of measures on security related grounds share the challenge of ensuring that these security-related objectives are duly achieved at the same time that unnecessarily restrictive measures are not endorsed. ${ }^{128}$

\section{SCREENING SYSTEMS ON NATIONAL SECURITY, NATIONAL ESSENTIAL SECURITY INTERESTS OR RELATED GROUNDS AND THEIR FOUNDATIONS}

Rules on market access or ownership limitation certainly remain in some countries, and mechanisms to control the future activity and functioning of foreign acquired national firms are also designed in some places. But, as stated, the very novelty nowadays is the growing development of screening systems of FDI on national security or related grounds by developed and emerging countries which, as a matter of principle and due to their limited scope, do not limit the full support of many of these countries to the idea of free movement of investment. National states may impose conditions on the entrance of aliens and they can also impose conditions on the entrance of FDI. ${ }^{129}$ All these screening

126 United States Government Accountability Office, Report to the Committee on Banking, Housing, and Urban Affairs, U.S. Senate, Sovereign Wealth Funds. Laws Limiting Foreign Investment Affect Certain U.S. Assets and Agencies Have Various Enforcement Processes, GAO-09-608 (Washington DC, 05.2009), p. 16 and Appendix II. Consider, 49 USC \ 40102(a)(15)(C).

127 See MAMOUNAS, Joseph, "Controlling Foreign Ownership of U.S. Strategic Assets: The Challenge of Maintaining National Security in a Globalized and Oil Dependent World". Law and Business Review of the Americas, v. 13, p. 381-395, 2007.

128 ORGANISATION FOR ECONOMIC CO-OPERATION AND DEVELOPEMENT. Building Trust and Confidence in International Investment. Report by countries participating in the "Freedom of Investment" Process March 2009. Paris: OECD, 2009. p. 10.

129 SORNARAJAH, Muthucumaraswamy. The International Law on Foreign Investment. 3 ed. Cambridge: CUP, 2010. p. 105. 
systems stand on different grounds but share the same idea of providing the state with a tool to protect certain industries or areas of the economy from FDI that either because its nature or origin can potentially generate threats to the national security of the host state.

Screening systems are usually mechanisms with a rather limited scope: the control of those particular FDI proposals that can threaten the national security of a specific host country. Because of their own nature they do not target all FDI and they habitually do not put under question the validity of the premise in favour of the free movement of FDI. They only refer to some specific FDI projects that encompass certain traits and that therefore are subject to evaluation on national security grounds by the public authorities of the host state. Which traits those are varies from country to country as does the philosophy on which the evaluation is undertaken and its results do too.

Screening mechanisms of evaluation of FDI on national security grounds are becoming rather popular worldwide. And their popularity poses certain issues as regards the principles and grounds on which they must be drafted for them to be compatible with the freedom of movement of capital and investment. Thus, the OECD identifies four key principles to be taken into account in relation to the development of any evaluation system of FDI on grounds of safeguard of national security interests, public order or related notions: non-discrimination, ${ }^{130}$ transparency and predictability of the system developed, ${ }^{131}$ proportionality ${ }^{132}$ and accountability. ${ }^{133}$

These pre-entry requisites are drafted in very many different ways and in any case will be subject to the network of treaties binding the host country in which the evaluation is undertaken. As a matter of principle and from a purely unilateral approach the evaluation by the competent agency or branch of the administration of the government of the host State should be made with the goal of ascertaining whether the FDI projected "brings tangible benefits" to it.

130 ORGANISATION FOR ECONOMIC CO-OPERATION AND DEVELOPEMENT. Recommendation of the Council on Guidelines for Recipient Country Investment Policies relating to National Security C(2009)63. Paris: OECD, 2009. Annex 1.

131 ORGANISATION FOR ECONOMIC CO-OPERATION AND DEVELOPEMENT. Accountability for Security-Related Investment Policies. Paris: OECD, 2008. p. 4.

132 ORGANISATION FOR ECONOMIC CO-OPERATION AND DEVELOPEMENT. Recommendation of the Council on Guidelines for Recipient Country Investment Policies relating to National Security C(2009)63. Paris: OECD, 2009. Annex 3.

133 ORGANISATION FOR ECONOMIC CO-OPERATION AND DEVELOPEMENT. Accountability for Security-Related Investment Policies. Paris: OECD, 2008. p. 4. Four additional principles are men-
Following the path of the US, with CFIUS, and despite the fear of international retaliation that the creation of this Committee implied, ${ }^{134}$ other countries have now replicated this move and are increasingly introducing clearance mechanisms to control FDI on a national security basis: in Australia the review is performed by the Foreign Investment Review Board (FIRB), in other countries like Canada, France or Germany this evaluation is undertaken by the Government through a specific Ministry. The approval of the FDI proposal will either come through an administrative act or by way of a contract or agreement between the host government administration and the foreign investor. ${ }^{135}$

The final relevance of the screening system designed by a particular country will depend on the grounds and goals on which the system stands and on the flexibility of its application. Usually, either specific industries or all sectors of the economy in relation, habitually, to FDI projects over certain thresholds are subject to review by an entitled authority. ${ }^{136}$ But many possibilities and combinations exist and the revision, like in the US, may also be done simple on grounds of national securi-

tioned by the World Bank Guidelines on the Treatment of Foreign Direct Investment: 1) Firstly, that the burden of proof should fall on those calling for restricting access to national markets and not the other way round; that is, on the host state. 2) Secondly, that SWFs as well as SOEs- do not constitute a homogeneous category and that these kinds of actors may vary deeply in major issues like size, funding, objectives, investment styles or sophistication. 3) Thirdly, that instead of stigmatizing the whole category of SWFs - and SOEs- by referring globally to all of them as negative FDI actors and subjecting all their FDI proposals to controls, only those SCEs that actually misbehave should be subject to control and evaluation. And, 4) Fourthly, in addition to all these requirements the World Bank recognizes the right of every state to draft legislation to govern the admission of FDI and the possibility of drafting a restricted list of investments. WORLD BANK. Guidelines on the Treatment of Foreign Direct Investment. No. II(3). Available in: < https://www.italaw.com/ documents/WorldBank.pdf>. Access on: 15 July 2018.

134 CONNELL, Paul; HUANG, Tian. "An Empirical Analysis of CFIUS: Examining Foreign Investment Regulation in the United States". The Yale Journal of International Law, v. 39, p. 131-150, 2014; CARROLL, James F. F., "Back to the Future: Redefining the Foreign Investment and National Security Act's Conception of National Security". Emory International Law Review, v. 23, p. 167-197, 2009.

135 SALACUSE, Jeswald W. The Three Laws of International Investment. National, Contractual and International Frameworks for Foreign Capital. Oxford: OUP, 2013. p. 109.

136 CLODFELTER, Mark A.; GUERRERO, Francesca M. S. « National Security and Foreign Government Ownership Restrictions on Foreign Investment: Predictability for Investors at the National Level ». In: SAUVANT, Karl P.; SACHS, Lisa E.; SCHMIT Jongbloed, Wouter P. F. (Ed.). Sovereign Investment. Oxford: Concerns and Policy Reactions, OUP, 2012. p. 175-7. 
ty implications of the FDI proposal without taking into account the final amount of the investment foreseen or the sector of the economy targeted. Or combine thresholds and other requirements like the need for the FDI proposals to render "net benefit to Canada" in the case of FDI targeting this country. ${ }^{137}$ The case of Japan, for instance, is significant of this trend. Article 27(3)(i) (a) \& (b) of the Foreign Exchange and Foreign Trade Act allows the Minister of Finance to screen any FDI that may potentially impair "national security", disturb the maintenance of "public order", hinder the protection of "public safety" or have an adverse effect on the "smooth management of the Japanese economy". None of these very broad and vague terms are defined and a large amount of discretion is granted to the government to evaluate the acceptance or not of the FDI project. It is finally for it to balance its positive stance towards FDI and its desire to have enough flexibility to stop non-desired FDI.

Also Australia has developed a system of case by case evaluation of foreign investment proposals to acquire a "substantial interest"138 or a "controlling" interest in an Australian corporation above a certain size or value, or an interest in Australia "urban land". ${ }^{139}$ The system stands on the acceptance of the freedom of FDI in Australia with the limitations set forth by the existing regulation. ${ }^{140}$ Foreign investment is generally welcomed

137 CLODFELTER, Mark A.; GUERRERO, Francesca M. S. « National Security and Foreign Government Ownership Restrictions on Foreign Investment: Predictability for Investors at the National Level ». In: SAUVANT, Karl P.; SACHS, Lisa E.; SCHMIT Jongbloed, Wouter P. F. (Ed.). Sovereign Investment. Oxford: Concerns and Policy Reactions, OUP, 2012. p. 178-9.

138 s 9 'FATA'. That means the acquisition of an interest of 15 per cent or more in an Australian business or corporation. Note BATH, Vivienne. "Foreign Investment, the National Interest and National Security - Foreign Direct Investment in Australia and China”. Sydney Law Review, v. 5, n. 34, p. -7, 2012; BOWMAN, Megan; GILLIGAN, George; O’BRIEN, Justin. "Foreign Investment Law and Policy in Australia: A Critical Analysis". Law and Financial Markets Review, v. 8, n. 1, p. 65-66, 2014; AUSTRALIAN GOVERNMENT. Foreign Investment Review Board, Foreign Investment Review Board. Annual Report 13/14, Commonwealth of Australia, Canberra, 2015. p. 54. 139 See 5 'FATA'. Any land in Australia that is not devoted to primary production, note BOWMAN, Megan; GILLIGAN, George; O'BRIEN, Justin. "Foreign Investment Law and Policy in Australia: A Critical Analysis". Law and Financial Markets Review, v. 8, n. 1, p. 66, 2014.

140 FDI is welcomed but at the same time the State has the right and the duty to "impose conditions and rules on how different stakeholders within its borders interact KALFADELLIS, Paul; GRAY, Judy; FREEMAN, Susan. The 'National Interest' and the Screening of Foreign Direct Investment in Australia, Monash University Business and Economics. Melbourne: Working Paper 14/06, 2006. p. 8. in Australia, traditionally "a capital hungry country". ${ }^{141}$ But at the same time it is said that the "community must have confidence that this investment is coming in on our terms and for our nation's benefit." ${ }^{142}$ The goal of the system is to determine whether the investment may run contrary to the "national interest" of Australia; those FDI proposals that are contrary to the "national interest" of the country are disallowed. What "national interest" actually means is not defined and a case-by-case evaluation is requested. ${ }^{143}$ This provides the government with considerable power in approving or disallowing FDI proposals.

Remarkable differences exist among the several screening systems designed. In some cases the screening system is solely designed to protect the national security of the country against potential harmful FDI; this would be the case of the US. On the contrary, other states refer to broader goals, such as the protection of "national interest", like in Australia. ${ }^{144}$ Or require the investment to be of "the net benefit" of the host country, as happens in Canada. In other nations, like France, the freedom of movement of capital and of investment coexist with the existence of some ideas of "economic patriotism" applied to filter some FDI projects. Some countries, like Germany do not have any special rule as regards sovereign driven FDI, whereas this kind of FDI is subject to a particular treatment in countries like Canada or the US. Also the designation of specific independent organisms in some countries -CFIUS in the US- contrasts with the broad powers granted to the go-

141 O'BRIEN, Justin; GILLIGAN, George; GREENACRE, Jonathan. The Great Game Rebooted or the Long March to Acceptance? The Legal and Policy Impediments to Chinese Investment in Australian Corporations and Business Opportunities, The University of New South Wales School of Law, Centre for Law, Markets and Regulation, CLMR Research paper series, Working Paper No. 12-4, Sydney, November 2012. p. 17.

142 AUSTRALIAN GOVERNMENT. The Treasury, Government tightens rules on foreign purchases of agricultural land. Joint media release with The Hon Tony Abbott MP, Prime Minister and The Hon Barnaby Joyce MP, Minister for Agriculture, Canberra. 05.2015. Available in: <http://jbh.ministers.treasury.gov.au/mediarelease/005-2015/>. Access on: 12 Jul. 2018.

143 FRIGON, Matthieu. The Foreign Investment Review Process in Canada. Publication No. 2011-42-E12 July 2011 Revised 21 July 2014. Ottawa: Background paper, Library of Parliament/Bibliothèque du Parlament, 2014. p. 9.

144 COBAU, John, "Legal Developments in U.S. National Security Reviews of Foreign Direct Investment (2006-2008)'. In: SAUVANT, Karl P.; SACHS, Lisa E.; SCHMIT Jongbloed, Wouter P. F. (Ed.). Sovereign Investment. Oxford: Concerns and Policy Reactions, OUP, 2012. p. 107. 
vernment in some other systems -Australia, Germany, France or the UK- in order to implement the process of evaluation of FDI on national security or related grounds. ${ }^{145}$

The legal basis referred to for this evaluation on national security grounds varies from country to country too; reference to competition law as a mechanism to control FDI on national security grounds in some countries -in the PRC- is in contrast with the enactment of special rules as regards this issue -US, Germany, France, Australia or, Canada-. These systems are envisaged in certain countries as a last resort instrument only applicable when no other legal device is available -the US-. As a matter of principle these tools should be considered as last resort mechanisms usually dependent on the application of other provisions and systems foreseen in the host state to monitor the market or some specific areas of it. The 2009 OECD Recommendation on Guidelines for Recipient Country Investment Policies Relating to national security explicitly supports this point. They should then be avoided when there are other existing measures adequate and appropriate to address national security concerns. ${ }^{146}$ Consequently, any system designed to control the entrance of foreign capital into the country should then come into play only when those other systems designed to monitor the normal activity of the market -free competition, transparency of the financial market...- have already been applied and not previously or in addition to them, as if it were a fully independent system applicable at the same time and level than the other ones.

But this is not the case in many other countries in which the system interplays in different ways with other legal mechanisms designed in the host country. For instance, on the one hand FDI in companies' shares that are listed on a stock or security exchange system will usually be subject to specific regulations and some conditions may be imposed to them. Additionally they may be subject to other applicable rules like those of competition law which are used to prevent dominant firms

145 JACKSON, James K. The Committee on Foreign Investment in the United States (CFIUS). Congressional Research Service, 7-5700, RL33388, Washington, six March 2014. p. 30; UNCTAD. World Investment Report 2016. Investor Nationality: Policy Challenges. New York and Geneva: United Nations, 2016. p. 94ff.

146 ORGANISATION FOR ECONOMIC CO-OPERATION AND DEVELOPEMENT. Recommendation of the Council on Guidelines for Recipient Country Investment Policies relating to National Security $C$, (2009)63 . Paris: OECD, 2009. Annex 3. -national and, in this case, foreign- to enter the market of the host country, ${ }^{147}$ or in the case of greenfield FDI the request for the investment to be made only through joint-ventures. They can also be submitted to the existing legislation on the privatization of certain formerly public owned enterprises which may bar certain FDI from state controlled enterprises or allow it only after approval by certain institutions or those that create a certain kind of shares with no sufficient voting rights to control the enterprise object of the investment. ${ }^{148}$ As a matter of fact, only when these rules have been implemented should national systems on control of FDI become applicable. However, reality seems to be rather different. For instance, the rejection in 2011 of the bid by the Singapore Exchange Ltd. to acquire a major interest in the Australian Stock Exchange, both of them private entities, was made not only on the basis of the 'FATA' but also taking into account that the Corporations Act $2001^{149}$ limits ownership by a person in the Australian Stock Exchange to a maximum of 15 per cent unless a special regulation is passed to increase this threshold. ${ }^{150}$

In addition to the existence of different bases and goals in the designation of the several existing national screening systems, as well as relevant disparities as regards their institutional structures, also the concept of national security or security related industries on which they habitually stand varies from country to country; from narrow definitions to broader interpretations that extend investment review procedures to critical infrastructure and strategic industries. Countries do not provide a "clear-cut definition" of national security in relation to foreign investment. Instead, in some cases only a number of sectors or activities that may potentially pose national security-related threats from a national securi-

147 SORNARAJAH, Muthucumaraswamy. The International Law on Foreign Investment. 3 ed. Cambridge: CUP, 2010. p. 92.

148 SALACUSE, Jeswald W. The Three Laws of International Investment. National, Contractual and International Frameworks for Foreign Capital. Oxford: OUP, 2013. p. 121-2; UNCTAD. The Protection of National Security in ILAs. UNCTAD Series on International Investment Policies for Development. New York/Geneva: UNCTAD/ DIAE/IA/2008/5, UNCTAD, 2009. p. 14.

\section{Corporations Act 2001, No. 50, 2001 s 850B.}

150 Note, Singapore finally walks from ASX bid, The Sydney Morning Herald (on line), 8 April 2011 <http://www.smh.com.au/business/ singapore-finally-walks-from-asx-bid-20110407-1d6o4.html> accessed 16 December 2017. See BATH, Vivienne. "Foreign Investment, the National Interest and National Security - Foreign Direct Investment in Australia and China". Sydney Law Review, v. 5, n. 34, p. 8, 2012. 
ty stand-point are identified. ${ }^{151}$ Finally, the content and depth of the screening procedure and the degree and amount of information required from the investor is different from jurisdiction to jurisdiction. ${ }^{152}$ In addition to these factors, potential consequences for investments considered to be problematic from a national security perspective vary and include full or partial investment prohibitions and the possibility of final approval under certain -present or future- conditions.

Screening systems developed by national legislators have mainly focussed in relation to M\&As proposals, mostly in the infrastructure, telecommunications, finance and energy sectors, with special intensity in those cases in which the foreign acquirer is controlled or owned by a foreign state. ${ }^{153}$ As figures of the practical implementation of national screening systems show, these systems should not "strike terror into the hearts of foreign direct investors" $" 154$. However, and despite existing statistics, they are said to play an additional subtle role as regards potential foreign direct investors in so far they both foster the self-constraint and control by foreign investors as regards the goals and conditions of their prospective investment operations, as well as their willingness to enter potential agreements with the administration of the host country. ${ }^{155}$

151 UNITED NATIONS CONFERENCE ON TRADE AND DEVELOPMENT. World Investment Report 2016. Investor Nationality: Policy Challenges. New York and Geneva: United Nations, 2016. p. $94-5$.

152 UNITED NATIONS CONFERENCE ON TRADE AND DEVELOPMENT. World Investment Report 2016. Investor Nationality: Policy Challenges. New York and Geneva: United Nations, 2016, p. $99-100$.

153 ORGANISATION FOR ECONOMIC CO-OPERATION AND DEVELOPEMENT. Interim report approved by the OECD Investment Committee at the fourth OECD Roundtable on Freedom of Investment. National Security and "Strategic" Industries on 30 March 2007 (reproduced in OECD, International Investment Perspectives: Freedom of Investment in a Changing World. Paris: OECD, 2007. p. 55. 154 ZARING, David. "CFIUS as a Congressional Notification Service". Southern California Law Review, v. 83, p. 81-106, 2009, as regards the US screening system.

155 ZARING, David. "CFIUS as a Congressional Notification Service". Southern California Law Review, v. 83, p. 106-109, 2009 or BELLINGER, John B. III and Townsend, Nicholas L., "Inside 'the CFIUS': US National Security Review of Foreign Investments". Global Trade and Customs Journal, v. 1, n. 6, p. 1-2, 2011.-stating certain operations that failed because of CFIUS- also as regards the US screening system. In the particular case of the US, the delays derived from a CFIUS investigation and the potentially negative publicity that can be associated to such an investigation have negatively affected some operations and have led the investor to withdraw them. See JACKSON, James K. The Exon-Florio National Security Test for Foreign Investment. Congressional Research Service, 7-5700, RL33312,
States are increasingly imposing national security or related conditions on the entrance of foreign investment into their territory on specific areas of the economy or firms, or coming from certain countries or investors. Theoretically speaking these mechanisms should combine procedural fairness with the protection of sensitive information, and to ensure a level of flexibility which is enough to offer protection from investments that generate legitimate concerns at the same time that avoid political interference. ${ }^{156}$ However, and significantly, the different screening systems introduced usually correspond with each other in the lack of clear definitions of some relevant notions on which they stand -national essential security interests, national security, control, critical infrastructure...-, in the use of some very vague guidelines or criteria to assert whether the investment is acceptable or not, and in the granting of a broad power to the administration in order to perform the requested evaluation. ${ }^{157}$

The drafting of these screening systems has taken place in an atmosphere of liberalization of investment and their introduction has finally constituted a sort of exception to it. Consequently, any security related condition imposed on foreign investment or any system designed to evaluate it on national security grounds should be narrowly-tailored, focussing only on really genuine national security risks. ${ }^{158}$ And their use as an excuse to impose hidden limitations to free trade and investment should be prevented. Therefore, it is not the potential benefits for the host country arising out of the FDI project but the risks for the host state that it may generate that should finally be taken into account by these sorts of schemes of evaluation of FDI proposals. However, the peril of politicisation of these kinds of instruments

Washington, 29 March 2013. p. 10-14 providing some examples. 156 VANDERMEULEN, Jackie; TREBILCOCK, Michael J. "Canada's Policy Response to Foreign Sovereign Investment: Operationalizing National Security Exceptions". Canadian Business Law Journal, v. 47, p. 392-394, 2009.

157 VANDERMEULEN, Jackie; TREBILCOCK, Michael J. "Canada's Policy Response to Foreign Sovereign Investment: Operationalizing National Security Exceptions". Canadian Business Law Journal, v. 47, p. 394, 2009; SAFARIAN, A. Edward, "The Canadian Policy Response to Sovereign Direct Investment”. In: SAUVANT, Karl P.; SACHS, Lisa E.; SCHMIT JONGBLOED, Wouter P. F. (Ed.). Sovereign Investment. Oxford: Concerns and Policy Reactions, OUP, 2012. p. 446.

158 Statement of the European Union and the United States on Shared Principles for International Investment of April $2012<$ http://trade. ec.europa.eu/doclib/docs/2012/april/tradoc_149331.pdf $>$ accessed 13 December 2017. 
exists and the potential negative consequences derived from a broad interpretation of the notion of national security remain. ${ }^{159}$

\section{SOME FINAL IDEAS: A "LONG AND WINDING" FUTURE TO COME}

Practice currently shows the changing landscape of FDI and the existence of some new attitudes maintained by certain countries as regards it that can finally affect the existing situation and its future developments, as well as the position and rights of current and prospective foreign investors. The empowerment of states in relation to FDI may finally end up creating some short-circuits with the idea of liberalization of FDI, mostly when certain positions in favour of the control or limitation of FDI on different grounds by host states generalize and could lead to a new wave of economic nationalism. ${ }^{160}$ It is necessary to build up a new equilibrium among the need for freedom of FDI, the right of states to ensure the preservation of certain policies or the satisfaction of some goals in their territory and the necessity for foreign investors to enjoy a clear and stable legal framework and a minimum level of protection for their investments.

The financial crisis, the change in the origin of the FDI derived from the new geo-strategic reality arising out of the crisis, the growing participation of SCEs in international trade or the terrorism fear, amongst other reasons, have led many countries to set forth mechanisms to evaluate FDI proposals before they are implemented and not once they have been developed. ${ }^{161}$

159 Thus, the White House statement on the US-China economic relations of 2015, explicitly states that, "The United States and China commit to limit the scope of their respective national security reviews of foreign investments (for the United States, the CFIUS process) solely to issues that constitute national security concerns, and not to generalize the scope of such reviews to include other broader public interest or economic issues. The United States and China commit that their respective national security reviews apply the same rules and standards under the law to each investment reviewed, regardless of country of origin..." (The White House. Office of the Press Secretary, Fact Sheet: U.S.-China Economic Relations, Washington D.C., 25 September 2015, <https://obamawhitehouse.archives.gov/thepress-office/2015/09/25/fact-sheet-us-china-economic-relations $>$ accessed 22 November 2017).

160 UNCTAD. Investment Policy Developments in G-20 Countries, Division on Investment and Enterprise. New York/Geneva: UNCTAD, 2009. p. 7.

161 Since 2006, at least eight different economies have introduced or reformed their legislation on national security based screening
As a matter of principle the protection of national security would invite states to explore the temptation of adopting an isolationist stance towards FDI, although economic reality makes this possibility highly unrealistic nowadays. ${ }^{162}$

This recognition should not impair the rights and expectations of investors by reducing the predictability, transparency, and enforceability of the national and international investment framework. And this implies that when restrictive FDI measures are considered necessary to protect national security or to ensure certain security-related policy goals, states should ensure that these measures are adopted on a non-discriminatory basis and that they respect the principles of transparency, proportionality and accountability. ${ }^{163}$

Even today it is not possible to speak of a global trend towards restrictiveness of FDI. Perhaps the liberalization of FDI momentum has stopped but no evidence exists that states have become significantly more restrictive since the emergence of the global financial crisis in 2007. ${ }^{164}$ No sign of backtracking of investment policy reforms exists so far. On the contrary a continued reform impetus in countries which traditionally have been the most restrictive remains. Nevertheless, the development of screening mechanisms in many countries of the world usually on national security, essential national interests or similar grounds could provide the future tool for this backtracking should the notion of national security be broadly interpreted as to encompass economic strategic areas or firms. Sta-

of FDI. (ie Canada (2009), China (2011 and 2015), Finland (2012), Germany (2017), Italy (2012), the Republic of Korea (2006), Poland (2015), and the Russian Federation (2008)). See UNCTAD. World Investment Report 2016. Investor Nationality: Policy Challenges. New York and Geneva: United Nations, 2016, p. 95-6. On another level, this move comes together with efforts by certain countries to recalibrate existing or future investment agreements amid a trend to enhance the regulatory power of governments and to lessen the rights of investors. ALVAREZ, José E. "Contemporary Foreign Investment Law: An "Empire of Law" or the "Law of Empire"?" Alabama Law Review, v. 609, p. 970, 2009.

162 MAMOUNAS, Joseph, "Controlling Foreign Ownership of U.S. Strategic Assets: The Challenge of Maintaining National Security in a Globalized and Oil Dependent World". Law and Business Review of the Americas, v. 13, p. 382, 2007.

163 OECD. Building Trust and Confidence in International Investment. Report by countries participating in the "Freedom of Investment" Process March 2009. Paris: OECD, 2009. p. 10.

164 THOMSEN, Stephen; MISTURA, Fernando. Is investment protectionism on the rise? Evidence from the OECD FDI Regulatory Restrictiveness Index OECD Global Forum on International Investment. Paris: OECD, 2017. p. 1-2. 
tes, mostly developed ones, are increasingly concerned about the potential non-economic goals of sovereign FDI and of the lack of reciprocity in the country of the investor. Additionally, MNEs may face limitations on outbound investment by their home states. No global restriction trend seems to exist today, but the future is not free of dangers: "complacency" in this area should be avoided. ${ }^{165}$

\section{References}

ALVAREZ, José E. "Contemporary Foreign Investment Law: an "Empire of Law" or the "Law of Empire"?" Alabama Law Review, v. 609, p. 43, 2009.

AUSTRALIAN GOVERNMENT. Foreign Investment Review Board, Foreign Investment Review Board. Annual Report 13/14, Commonwealth of Australia, Canberra, 2015.

AUSTRALIAN GOVERNMENT. The Treasury, Government tightens rules on foreign purchases of agricultural land. Joint media release with The Hon Tony Abbott MP, Prime Minister and The Hon Barnaby Joyce MP, Minister for Agriculture, Canberra. 05.2015. Available in: <http://jbh.ministers.treasury.gov.au/media-release/005-2015/>. Access on: 12 Jul. 2018.

BATH, Vivienne. "Foreign Investment, the National Interest and National Security - Foreign Direct Investment in Australia and China". Sydney Law Review, v. 5, n. 34, 2012.

BELLINGER, John B. III and Townsend, Nicholas L., "Inside 'the CFIUS': US National Security Review of Foreign Investments". Global Trade and Customs Journal, v. 1, n. 6, 2011.

BITZENIS, Aristidis. Globalization and Foreign Direct Investment". In: BITZENIS, Aristidis, VLACHOS, Vasileios A.; PAPADIMITRIOU, Pyrros. (Ed.). Mergers and Acquisitions as the Pillar of Foreign Direct Investment. New York: Palgrave McMillan, 2012.

BOWMAN, Megan; GILLIGAN, George; O'BRIEN, Justin. "Foreign Investment Law and Policy in Australia: A Critical Analysis". Law and Financial Markets Review, v.

165 THOMSEN, Stephen; MISTURA, Fernando. Is investment protectionism on the rise? Evidence from the OECD FDI Regulatory Restrictiveness Index OECD Global Forum on International Investment. Paris: OECD, 2017. p. 6.
8, n. 1, p. 65, 2014.

CABINET OFFICE, ECONOMIC AND SOCIAL RESEARCH INSTITUTE. FY2015 Annual Survey of Corporate Behavior. Press Release, Tokio, 26 June 2016. Available in: <http://www.esri.cao.go.jp/en/stat/ank/ h27ank/h27ank_press.pdf>. Access on: 13 Jul. 2018.

CARROLL, James F. F., "Back to the Future: Redefining the Foreign Investment and National Security Act's Conception of National Security". Emory International Law Review, v. 23, p. 167, 2009.

CHAISSE, Julien; CHAKBABORTY, Debashis; MUKHERJEE, Jaydeep, "Emerging Sovereign Wealth Funds in the Making: Assessing the Economic Feasibility and Regulatory Strategies". Journal of World Trade, v. 45, n. 4, p. 837, 2011.

CHALAMISH, Efraim. "Global Investment Regulation and Sovereign Funds". Theoretical Inquiries in Law, v. 13, n. 2, p. 645, 2012.

CLODFELTER, Mark A.; GUERRERO, Francesca M. S. « National Security and Foreign Government Ownership Restrictions on Foreign Investment: Predictability for Investors at the National Level ». In: SAUVANT, Karl P.; SACHS, Lisa E.; SCHMIT Jongbloed, Wouter P. F. (Ed.). Sovereign Investment. Oxford: Concerns and Policy Reactions, OUP, 2012. p. 175.

COBAU, John, "Legal Developments in U.S. National Security Reviews of Foreign Direct Investment (20062008)'. In: SAUVANT, Karl P.; SACHS, Lisa E.; SCHMIT Jongbloed, Wouter P. F. (Ed.). Sovereign Investment. Oxford: Concerns and Policy Reactions, OUP, 2012. p. 107.

CONNELL, Paul; HUANG, Tian. "An Empirical Analysis of CFIUS: Examining Foreign Investment Regulation in the United States". The Yale Journal of International Law, v. 39, p. 131, 2014.

DIMOPOULOS, Angelos. EU Foreign Investment Law. Oxford: OUP, 2011.

DIXIT, Avinash. "International Trade, Foreign Direct Investment, and Security". The Annual Review of Economics, v. 3, p. 191, 2011.

DOBSON, Wendy. "China's State-Owned Enterprises and Canada's Foreign Direct Investment Policy". Canadian Public Policy, v. 43, 2017.

DOLZER, Rudolf; SCHREUER, Christoph. Principles 
of International Investment Law. 2. ed. Oxford: OUP, 2012. DREZNER, Daniel W.. "Sovereign Wealth Funds and the (In)security of Global Finance". Fall/Winter Journal of International Affairs, v. 62, p. 115, 2008.

ECONOMOU, Persephone; SAUVANT, Karl P. "Recent Trends and Issues in Foreign Direct Investment 2010". Yearbook on International Investment Law \& Policy, v. 3, p. 3, 2010-2011.

ESPLUGUES, Carlos. "La propuesta de reglamento estableciendo un marco para la evaluación de las inversiones extranjeras directas en la Unión Europea de septiembre de 2017". Cuadernos de Derecho Transnacional, v. 10, n. 1, 164, 2018.

ESPLUGUES, Carlos. El control de las inversiones extranjeras directas. Valencia: Tirant lo Blanch, 2018.

ESPLUGUES, Carlos. Foreign Investment, Strategic Assets and National Security. Cambridge: Intersentia, 2018.

FONTAGNÉ, Lionel. Foreign Direct Investment and International Trade: Complements or Subtitutes? Paris: OECD Science, Technology and Industry Working Papers, 1993/03, OECD Publishing, 1993.

FRIGON, Matthieu. The Foreign Investment Review Process in Canada. Publication No. 2011-42-E12 July 2011 Revised 21 July 2014. Ottawa: Background paper, Library of Parliament/Bibliothèque du Parlament, 2014.

GILLIGAN, George; BOWMAN, Megan; O'BRIEN, Justin. The Global Impact of State Capital, The University of New South Wales School of Law, Centre for Law, Markets and Regulation, CLMR Research paper series, Working Paper n. 13-2, Sydney, July 2013.

GILSON, Ronald; MILHAUPT, Curtis. "Sovereign Wealth funds and Corporate Governance: A Minimalist Response to the New Merchantilism". Standford Law Review, v. 60, p. 1345, 2008.

GÖKGÜR, Nilgün. "Are Resurging State-Owned Enterprises Impeding Competition Overseas?". In: SAUVANT, Karl P.; REIMER, Jennifer. (Ed.). FDI Perspectives: issues in International Investment. 2. ed. New York: VCC, 2012. p. 26.

GOLDING, Greg. "Australia's Experience with Foreign Direct Investment by State Controlled Entities: A Move towards Xenophobia or Greater Openness?" Seattle University Law Review, v. 37, p. 533, 2014.

GOLUB, Stepehn S. "Opennes to Foreign Direct In- vestment in Services: An International Comparative Analysis". The World Economy, p. 1245, 2009.

GOLUB, Stephen S. Measures of Restrictions on Inward Foreign Direct Investment for OECD Countries. Paris: OECD, 2003. (Economic Department Working Papers, No. 357, OECD Publishing).

GRAHAM, Edward M.; MARCHICK, David M. U.S. National Security and Foreign Direct Investment (Institute for International Economics. Washington, 2006.

HANEMANN, Thilo; ROSEN, Daniel H. China Invests in Europe Patterns, Impacts and Policy Implications. New York: Rhodium Group, 2012.

HANSON, Fergus. Australia and New Zealand in the World Public Opinion and Foreign Policy. Lowy Institute for International Policy. Sydney. 2012. Available in: <https:// www.lowyinstitute.org/publications/lowy-institutepoll-2012-public-opinion-and-foreign-policy>. Access on: 14 Jul. 2018.

HEINEMANN, Andreas. "Government Control of Cross-Border M\&A: Legitimate Regulation or Protectionism? Control of Cross-Border M\&A”. Journal of International Economic Law, v. 15, n. 4, p. 843, 2012.

INTELLIGENCE AND SECURITY COMMITTEE. Foreign involvement in the Critical National Infrastructure The implications for national security (Chairman: The Rt. Hon. Sir Malcolm Rifkind, MP) Presented to Parliament by the Prime Minister on behalf of Her Majesty, Cm 862, June 2013.

INVESTMENT CLIMATE ADVISORY SERVICES WORLD BANK GROUP. Investing Across Borders 2010. Indicators of foreign direct investment regulation in 87 economies. Washington: World Bank, 2010.

JACKSON, James K. Foreign Investment and National Security: Economic Considerations, Congressional Research Service, 7-5700, RL34561, Washington, 4 April 2013.

JACKSON, James K. The Committee on Foreign Investment in the United States (CFIUS). Congressional Research Service, 7-5700, RL33388, Washington, six March 2014.

JACKSON, James K. The Exon-Florio National Security Test for Foreign Investment. Congressional Research Service, 7-5700, RL33312, Washington, 29 March 2013.

JOST, Thomas. "Sovereign Wealth Funds and the German Reaction". In: SAUVANT, Karl P.; SACHS, Lisa E. SCHMIT JONGBLOED, Wouter P.F. (Ed.). Sove- 
reign Investment. Oxford: Concerns and Policy Reactions, OUP, 2012. p. 453.

KALFADELLIS, Paul; GRAY, Judy; FREEMAN, Susan. The 'National Interest' and the Screening of Foreign Direct Investment in Australia, Monash University Business and Economics. Melbourne: Working Paper 14/06, 2006.

KURTZ, Jürgen. "A General Investment Agreement in the WTO? Lessons from Chapter 11 of NAFTA and the OECD Multilateral Agreement on Investment". University of Pennsylvania Journal of International Economic Law, v. 243, n. 3, p. 713, 2002.

LEAL-ARCAS, Rafael. "Towards the Multilateralization of International Investment Law". The Journal of World Investment \& Trade, v. 10, p. 865, 2009.

LEE, Yong-Shik. Foreign Direct Investment and Regional Trade Liberalization: A Viable Answer for Economic Development? Journal of World Trade, v. 39, n. 4, p. $701,2005$.

LONG, Guoquiang. "China's policies on FDI: review and evaluation". In: MORAN, Theodore H.; GRAHAM, Edward M.; BLOMSTRÖM, Magnus. (Ed.). Does foreign direct investment promote development? Washington: (Institute for International Economics, 2005. p. 315.

MALAWER, Stuart S. "Global Mergers and National Security". Virginia Lawyer Magazine, p. 33, Dec. 2006.

MAMOUNAS, Joseph, "Controlling Foreign Ownership of U.S. Strategic Assets: The Challenge of Maintaining National Security in a Globalized and Oil Dependent World". Law and Business Review of the Americas, v. 13, p. 381, 2007.

MORAN, Theodore H. "Foreign Acquisitions and National Security: What are Genuine Threats? What Are Implausible Worries?" In: DRABEK, Zdenek; MAVROIDIS, Petros C. (Ed.). Regulation of Foreign Investment Challenges to International Harmonization. New York: Columbia University, 2013. p. 372. (Singapore World Scientific, World Studies in International Economics, v. 21)

MORAN, Theodore H. Chinese Foreign Direct Investment in Canada: threat or Opportunity?. Ottawa: Canadian Council of Chief Executives/Conseil Canadien des Chiefs d'Enterprise, 2012.

MUCHLINSKI, Peter T. "Corporations and the Uses of Law: International Investment Arbitration as a "Multilateral Legal Order". Oñati Socio-Legal Series, v. 1, n. 4, p. 3, 2011.

MUCHLINSKI, Peter T. Multinational Enterprises \& the Law. 2. ed. Oxford: OUP, 2007.

O'BRIEN, Justin; GILLIGAN, George; GREENACRE, Jonathan. The Great Game Rebooted or the Long March to Acceptance? The Legal and Policy Impediments to Chinese Investment in Australian Corporations and Business Opportunities, The University of New South Wales School of Law, Centre for Law, Markets and Regulation, CLMR Research paper series, Working Paper n. 12-4, Sydney, November 2012.

ORGANIZATION FOR ECONOMIC CO-OPERATION AND DEVELOPMENT. Accountability for Security-Related Investment Policies. Paris: OECD, 2008.

ORGANIZATION FOR ECONOMIC CO-OPERATION AND DEVELOPMENT. Building Trust and Confidence in International Investment. Report by countries participating in the "Freedom of Investment" Process March 2009. Paris: OECD, 2009.

ORGANIZATION FOR ECONOMIC CO-OPERATION AND DEVELOPMENT. FDI in Figures. April 2017. 1-2. Available in: <http://www.oecd.org/daf/ inv/investment-policy/FDI-in-Figures-April-2017. pdf $>$. Access on: 13 Jul. 2018.

ORGANIZATION FOR ECONOMIC CO-OPERATION AND DEVELOPMENT. Interim report approved by the OECD Investment Committee at the fourth OECD Roundtable on Freedom of Investment. National Security and "Strategic" Industries on 30 March 2007 (reproduced in OECD, International Investment Perspectives: Freedom of Investment in a Changing World. Paris: OECD, 2007.

ORGANIZATION FOR ECONOMIC CO-OPERATION AND DEVELOPMENT. International Investment Perspectives. Paris: OECD, 2006.

ORGANIZATION FOR ECONOMIC CO-OPERATION AND DEVELOPMENT. Novel Features in OECD Countries' Recent Investment Agreements: An Overview. Paris: OECD, 2005.

ORGANIZATION FOR ECONOMIC CO-OPERATION AND DEVELOPMENT. Protection of "Critical Infrastructure" and the Role of Investment Policies Relating to National Security. Paris: OECD, 2008.

ORGANIZATION FOR ECONOMIC CO-OPERATION AND DEVELOPMENT. Recommendation of the 
Council on Guidelines for Recipient Country Investment Policies relating to National Security C(2009)63. Paris: OECD, 2009.

ORGANIZATION FOR ECONOMIC CO-OPERATION AND DEVELOPMENT. Roundtable on Freedom of Investment 20.19 March 2014 Summary of Roundtable discussions by the OECD Secretariat. Paris: OECD, 2014.

OLIVER, Alex. The Lowy Institute Poll 2014. Lowy Institute for International Policy. Sydney, 2014. Available in: <https://www.lowyinstitute.org/sites/default/ files/2014_lowy_institute_poll_0.pdf $>$. Access on: 15 Jul. 2018.

PISTOR, Katharina. "Sovereign Wealth Funds and Global Finance". In: SAUVANT, Karl P.; SACHS, Lisa E.; SCHMIT Jongbloed, Wouter P. F. (Ed.). Sovereign Investment. Oxford: Concerns and Policy Reactions, OUP, 2012. p. 145.

POLLAN, Thomas. Legal Framework for the Admission of FDI. Utrecht: Eleven International Publishing, 2006.

ROSE, Paul. "Sovereigns as Shareholders". North Carolina Law Review, v. 87, p. 101, 2008.

ROSECRANCE, Richard; THOMPSON, Peter. "Trade, Foreign Investment, and Security". Annual Review of Political Science, v. 6, p. 377, 2003.

SACHS, Jeffrey D. "Foreign Investment and the Changing Global Economic Reality". In: ALVAREZ, José E. et al. (Ed.). The Evolving International Investment Regime Expectations. Oxford: Realities, Options, OUP, 2011.

SACHS, Lisa E.; SAUVANT, Karl P., "BITs, DTTs, and FDI Flows: An Overview", In: SAUVANT, Karl P.; SACHS, Lisa E. The Effect of Treaties on Foreign Direct Investment. Bilateral Investment Treaties, Double Taxation Treaties, and Investment Flows. Oxford: OUP, 2009.

SAFARIAN, A. Edward, "The Canadian Policy Response to Sovereign Direct Investment”. In: SAUVANT, Karl P.; SACHS, Lisa E.; SCHMIT JONGBLOED, Wouter P. F. (Ed.). Sovereign Investment. Oxford: Concerns and Policy Reactions, OUP, 2012. p. 431.

SALACUSE, Jeswald W. The Three Laws of International Investment. National, Contractual and International Frameworks for Foreign Capital. Oxford: OUP, 2013.

SANYAL, Kali. Foreign investment in Australian agriculture, Parliament of Australia. Department of Parliamentary
Services, Research Paper, Parliament of Australia, Canberra 18 February 2014.

SAUVANT, Karl P. "Driving and Countervailing Forces: a Rebalancing of National FDI Policies". Yearbook on International Investment Law \& Policy, p. 215, 2008.

SAUVANT, Karl P. "Is the United States Ready for FDI from China? Overview". In: SAUVANT, Karl P. (Ed.). Investing in the United States Is the US Ready for FDI from China, Studies in International Investment. Edward Elgar: Cheltenham/Northampton, 2009. p. 10.

SAUVANT, Karl P. “The FDI recession has begun”. In: SAUVANT, Karl P. et al. FDI Perspectives Issues in International Investment. New York: Vale Columbia Center on Sustainable International Investment, Columbia University, 2011.

SAUVANT, Karl P. "The Rise of International Investment, Investment Agreements and Investment Disputes”. In: SAUVANT, Karl P.; WITH CHISWICKPATTERSON, Michael. (Ed.). Appeals Mechanism in International Investment Disputes. New York: OUP, 2008.

SAUVANT, Karl P. FDI Protectionism Is on the Rise, Policy Research Working Paper 5052, The World Bank Poverty Reduction and Economic Management Network, International Trade Department World Bank, Washington, September 2009.

SAUVANT, Karl P.; GOVITRIKAR, Vishwas P.; DAVIES, Ken. MNEs from Emerging Markets: New Players. In: THE WORLD FDI Market. New York: Vale Columbia Center, 2011.

SAUVANT, Karl P.; ORTINO, Federico. Improving the International Investment Law and Policy Regime: Options for the Future. Helsinki: Ministry for Foreign Affairs of Finland, 2013.

SORNARAJAH, Muthucumaraswamy. The International Law on Foreign Investment. 3. ed. Cambridge: CUP, 2010.

SPEARS, Suzanne A. "The Quest for Policy Space in a New Generation of International Investment Agreements". Journal of International Economic Law, v. 13, n. 4, p. $1037,2010$.

STATISTIC BRAIN. Job Overseas Outsourcing Statistics. Available in: <http://www.statisticbrain.com/ outsourcing-statistics-by-country/>. Access on: 13 Jul. 2018.

SUMNER, Andrew. "Foreign Direct Investment in De- 
veloping Countries: Have We Reached a Policy 'Tipping Point'?”. Third World Quarterly, v. 29, n. 2, p. 239, 2008.

THE SENATE, ECONOMIC REFERENCES COMMITTEE. Foreign investment by state-owned entities. Canberra, September 2009. Available in: <http://www.aph. gov.au/Parliamentary_Business/Committees/Senate/ Economics/Completed_inquiries/2008-10/firb_09/ report/index> Access on: 15. July 2018.

THE TREASURER. Australia's Foreign Investment Policy Our Approach. July 1st, 2016. Available in: < https:/ / firb. gov.au/files/2015/09/Australias-Foreign-InvestmentPolicy-2016-2017.pdf>. Access on: 15 Jul. 2018.

THOMSEN, Stephen; MISTURA, Fernando. Is investment protectionism on the rise? Evidence from the OECD FDI Regulatory Restrictiveness Index OECD Global Forum on International Investment. Paris: OECD, 2017.

TRAKMAN, Leon E.; RANIERI, Nicola W. "Foreign Direct Investment: A Historical Perspective". In: TRAKMAN, Leon E.; RANIERI, Nicola W. (Ed.). Regionalism in International Investment Law. Oxford: OUP, 2013. p. 19.

UNITED NATIONS CONFERENCE ON TRADE AND DEVELOPMENT. Investment Policy Developments in G-20 Countries, Division on Investment and Enterprise. New York/Geneva: UNCTAD, 2009.

UNITED NATIONS CONFERENCE ON TRADE AND DEVELOPMENT. Investment Policy Framework for Sustainable Development, Doc. Geneva: UNCTAD/ DIAE/PCB/2015/5, UNCTAD, 2015.

UNITED NATIONS CONFERENCE ON TRADE AND DEVELOPMENT. The Protection of National Security in IIAs. UNCTAD Series on International Investment Policies for Development. New York/Geneva: UNCTAD/DIAE/IA/2008/5, UNCTAD, 2009.

UNITED NATIONS CONFERENCE ON TRADE AND DEVELOPMENT. World Investment Report 2010. Investing in a Low-Carbon Economy. New York and Geneva: United Nations, 2010.

UNITED NATIONS CONFERENCE ON TRADE AND DEVELOPMENT. World Investment Report 2015. Reforming International Investment Governance. New York and Geneva: United Nations, 2015.

UNITED NATIONS CONFERENCE ON TRADE AND DEVELOPMENT. World Investment Report 2016. Investor Nationality: Policy Challenges. New York and
Geneva: United Nations, 2016.

UNITED STATES GOVERNMENT ACCOUNTABILITY OFFICE. Report to the Committee on Banking, Housing, and Urban Affairs, U.S. Senate, Sovereign Wealth Funds. Laws Limiting Foreign Investment Affect Certain U.S. Assets and Agencies Have Various Enforcement Processes, GAO-09-608, Washington DC, 05.2009.

VADI, Sara. "Fragmentation or Cohesion? Investment versus Cultural Protection Rules". Journal of World Investment and Values, v. 10, p. 573, 2009.

VANDERMEULEN, Jackie; TREBILCOCK, Michael J. "Canada's Policy Response to Foreign Sovereign Investment: Operationalizing National Security Exceptions". Canadian Business Law Journal, v. 47, p. 392, 2009.

VANDUZER, J. Anthony; SIMONS, Penelope; MAYEDA, Graham. Integrating Sustainable Development into International Investment Agreements: a Guide for Developing Countries (prepared for the Commonwealth Secretariat by the authors, London, 2012.

WAYMOUTH, Crispin. 'Is 'Protectionism' a Useful Concept for Company Law and Foreign Investment Policy? An EU Perspective". In: BERNITZ, Ulf; RINGE, Wolf-Georg. (Ed.). Company Law and Economic Protectionism New Challenges to European Integration. Oxford: OUP, 2010. p. 35.

WEISS, Martin A. Sovereign Wealth Funds: Background and Policy Issues for Congress. CRS Report for Congress, Congressional Research Service, RL34336, Washington 3 September 2008.

WORLD BANK. Guidelines on the Treatment of Foreign Direct Investment. No. II(3). Available in: < https://www. italaw.com/documents/WorldBank.pdf $>$. Access on: 15 July 2018.

YANNACA-SMALL, Katia. "Essential Security Interests under International Investment Law". In: ORGANISATION FOR ECONOMIC CO-OPERATION AND DEVELOPMENT. International Investment Perspectives: Freedom of Investment in a Changing World. Paris: OECD, 2007. p. 94.

ZARING, David. "CFIUS as a Congressional Notification Service". Southern California Law Review, v. 83, p. 81, 2009. 
Para publicar na Revista de Direito Internacional, acesse o endereço eletrônico www.rdi.uniceub.br ou www.brazilianjournal.org.

Observe as normas de publicação, para facilitar e agilizar o trabalho de edição. 